\title{
The Perspective of Large-Scale Production of Algae Biodiesel
}

\author{
Mladen Bošnjaković ${ }^{1, *(\mathbb{C})}$ and Nazaruddin Sinaga ${ }^{2}$ (1) \\ 1 Technical Department, University of Slavonski Brod, Trg Stjepana Miletića 12, 35000 Slavonski Brod, Croatia \\ 2 Mechanical Engineering Department, Faculty of Engineering, Diponegoro University, Semarang 50275, \\ Central Java, Indonesia; nsinaga19.undip@gmail.com \\ * Correspondence: mladenb@vusb.hr
}

Received: 19 October 2020; Accepted: 13 November 2020; Published: 18 November 2020

\begin{abstract}
We have had high expectations for using algae biodiesel for many years, but the quantities of biodiesel currently produced from algae are tiny compared to the quantities of conventional diesel oil. Furthermore, no comprehensive analysis of the impact of all factors on the market production of algal biodiesel has been made so far. This paper aims to analyze the strengths, weaknesses, opportunities, and threats associated with algal biodiesel, to evaluate its production prospects for the biofuels market. The results of the analysis show that it is possible to increase the efficiency of algae biomass production further. However, because the production of this biodiesel is an energy-intensive process, the price of biodiesel is high. Opportunities for more economical production of algal biodiesel are seen in integration with other processes, such as wastewater treatment, but this does not ensure large-scale production. The impact of state policies and laws is significant in the future of algal biodiesel production. With increasingly stringent environmental requirements, electric cars are a significant threat to biodiesel production. By considering all the influencing factors, it is not expected that algal biodiesel will gain an essential place in the fuel market.
\end{abstract}

Keywords: algae; biodiesel; large-scale production; SWOT (strengths, weaknesses, opportunities, and threats); transport

\section{Introduction}

Fossil fuel is an unsustainable source of energy and directly linked to air, water, land degradation, and climate change. A large proportion of fossil fuels is consumed as motor fuel in various means of transportation, power plants, and agriculture. On the other hand, as the number of transport facilities increases significantly and, thus, the amount of fuel they consume, the world faces the challenge of finding alternative fuels, since the reserves of fossil fuels are reduced.

In 2018, the energy end-use in the EU-28 showed three dominant sectors: industry (25.8\%), households (26.1\%), and transportation (30.5\%) [1]. In the European Union, the transportation sector contributes to $25 \%$ of greenhouse gas emissions [2], 36.48\% emission of NOx, and $10.67 \%$ emission of PM2.5 [3].

Therefore, one of the strategic goals is to reduce emissions from transportation. To achieve this, it is essential to gradually substitute fossil fuels with renewable energy sources. In that sense, biofuels can play a remarkable role. Besides this, biofuel production can increase employment in rural areas and, thus, help their development.

In this regard, one of the energy alternatives is biodiesel. Globally, biodiesel is mostly produced from palm oil ( $31 \%)$, soybean $(27 \%)$, oilseed rape $(20 \%)$, and used cooking oil $(10 \%)$. In the EU biodiesel is produced from oilseed rape (44\%), palm oil ( $29 \%)$, used cooking oil $(15 \%)$, and soybean oil $(5 \%)$. The rests represent sunflower, coconut, peanuts, hemp, jatropha, corn, and algae [4]. 
Algal biodiesel is an alternative to decrease the consumption of fossil fuels. Compared to classical bioenergy crops, algae cultivation gives much higher yields, which is a significant advantage. Particular algae species (Schizochytrium sp., Nitzschia sp., and Botyococcus braunii) contain over $50 \%$ of the oil reduced to dry biomass, which can be extracted and processed into fuel $[5,6]$. Several fuel types can be produced from algae, such as bioethanol, biodiesel, methane, aircraft fuel (kerosene), biobutanol, biogas, and green diesel.

Microalgae grow in fresh or saltwater [7], but also in extreme conditions [5]. Therefore, they are present in diverse ecosystems, like dormant and liquid aquatic ecosystems [6]. Microalgae can yield significant amounts of lipids that are the basis of biodiesel production, as opposed to macroalgae that tend to produce sugars and other carbohydrates instead of lipids. The macroalgae oil content is less than $5 \%$ of their dry weight, so they are not economically viable feedstock for biodiesel production [6] and are not be further analyzed in this paper. Algae convert sugars into oil and biomass from which, in addition to biofuels, various chemicals, pharmaceuticals, foodstuffs, and cosmetics can be obtained [8]. Obtaining biodiesel from algae is technically feasible and sustainable, thus putting this technology in an excellent position to potentially and methodically replace oil-derived fuel [9].

Although many reports state that obtaining biodiesel from algae has a perspective [10-12], the production of large-scale biodiesel from algae is not yet commercially viable. In the production of biodiesel, only those microalgae that contain a high proportion of oil and have a high productivity of biomass and are resistant to various environmental influences can be used. So far, no known microalgae species have these properties [13].

This paper overviews the outline of elements of sustainability and the algae potential for large-scale production of biodiesel. The SWOT (strengths, weaknesses, opportunities, and threats) analysis was conducted to facilitate the study.

The structure of the work is as follows. Section 1 introduces the topic and briefly addresses the issues. Section 2 describes the methods and material of the study. In Section 3, the data regarding the technical aspects of biodiesel production from algae are presented. The SWOT analysis was performed in Section 4, for the identification of the strength and potential of technical improvement in the technology of biodiesel production, the weakness, and possible threats of environmental issues. Discussion and critical analysis of all involved aspects are conducted in this section, to evaluate the potential of biodiesel production on a commercial basis. The conclusions are presented in Section 5 .

\section{Materials and Methods}

The information to carry out the study is based on papers at conferences, journals, and specific scientific literature and scientific databases, including Science Direct, Scopus, MDPI, Google Academic, Google Scholar, and specific topics on the web pages. This paper also utilizes certain reports and documents published by the European Union (EU Directives and Eurostat Publications), International Renewable Energy Agency [14-16], and European Environment Agency [3] that relate to algae biodiesel production. Internet sources and scientific articles that do not have reliable and cited data sources were excluded from consideration.

In this review, a SWOT analysis was carried out to analyze the overall position and perspective of large-scale biodiesel production as an alternative energy source in transport. Although there are more complex approaches to the analysis of the subject matter, such as the hybrid decision-making method developed by Naeini et al. [17], the classical SWOT analysis, described by Weihrich [18], can be perfectly applied in this case. A SWOT analysis organizes strengths, weaknesses, opportunities, and threats into a structured list. Strengths and weaknesses include internal factors in the company, such as internal organizational structure, available equipment, and technologies, while opportunities and threats include external factors, such as market competitors and government policy.

Ordinarily, a SWOT analysis allows researchers to identify potential threats and weaknesses and improve existing strategies by utilizing new opportunities or neutralizing potential threats [19]. 
Therefore, the analysis conducted in this paper can provide a more comprehensive overview of the biodiesel production potential at the commercial scale and facilitate decision-making for stakeholders.

\section{Production of Algal Biodiesel}

Algae use light as an energy source to generate biomass from water and $\mathrm{CO}_{2}$ through photosynthesis. Algae also require nitrogen and phosphorus as significant nutrients [8]. Various factors influence the optimal growth of algae and their lipid accumulation. Among others, this includes the availability of micro and macronutrients [20], light intensity [21], $\mathrm{CO}_{2}$, water temperature [22], and $\mathrm{pH}$ [23]. Optimum conditions are not equal for all algae and mainly refer to the temperature and intensity of light.

Therefore, the global feedstock potentials from algae cultivation are limited in areas with enough radiation, water, and nutrients. Most species of algae favor the temperature from 20 to $30{ }^{\circ} \mathrm{C}$ [9]. Theoretically, microalgae can transform $12.8-14.4 \%$ of average solar irradiation into biomass [24] with a yield of $77 \mathrm{~g} / \mathrm{m}^{2} /$ day, which gives approximately $280,000 \mathrm{~kg} / \mathrm{ha} /$ year of biomass [25]. However, the actual biomass yield achieved so far from algae is much lower [6].

Asia (2.5 EJ/year) and Africa (0.75 EJ/year) have the highest potential for algal biomass cultivation until 2035. North and South America (0.75 EJ/year), Oceania (0.2 EJ/year), and, finally, Europe $(0.15 \mathrm{EJ} /$ year $)$ follow them. The assessment of the potential of the algal raw material is very unreliable because the algae cultivation systems are still in the development phase [14].

Numerous algae farming systems are being successfully developed today, from outdoor ponds and indoor photobioreactors, heterotrophic productions to the systems that combine these systems. Each system aims at the faster growth of algae biomass for the production of biofuels or other industrial products [8]. Algae can grow on incapable land for growing food crops, and since they can use saltwater, there is much less need for fresh water, whose quantities are limited. Production of hundreds of thousands of barrels of diesel per day requires less than $1 \%$ of the land used for soybean and corn cultivation. Microalgae can yield more oil per hectare of the occupied area compared to traditional biodiesel crops (Table 1). For example, the yield of algae with $30 \%$ oil in dry biomass is up to $58,700 \mathrm{~L} /$ ha/year, which is much higher compared to oilseed rape or soybeans $[26,27]$.

Table 1. Yield of algae and other biodiesel crops.

\begin{tabular}{|c|c|c|c|c|c|}
\hline Crop & $\begin{array}{l}\text { Oil Yield } \\
\text { (L/ha/year) }\end{array}$ & $\begin{array}{c}\text { Biodiesel } \\
\text { Productivity } \\
\text { (kg/ha/year) }\end{array}$ & Crop & $\begin{array}{c}\text { Oil Yield } \\
\text { (L/ha/year) }\end{array}$ & $\begin{array}{c}\text { Biodiesel } \\
\text { Productivity } \\
\text { (kg/ha/year) }\end{array}$ \\
\hline Rapeseed & 1190 & 862 & Sunflower & 952 & 946 \\
\hline Oil palm & 5950 & 4747 & Jatropha & 1892 & 656 \\
\hline Corn & 172 & 152 & Microalgae * & 58,700 & 51,927 \\
\hline Soybean & 446 & 562 & Microalgae $* *$ & 136,900 & 121,104 \\
\hline
\end{tabular}

\subsection{Algae Farming Systems}

When choosing an algae farming system, it is crucial to select an excellent location to obtain the wished result. Presently, there are several algae farming systems. The most widespread system of open ponds can be raceway or circular, with or without water stirring [28]. The unstirred ponds are the simplest because they have no water stirring device and, therefore, they are the cheapest [29]. From $20 \%$ to $40 \%$ of the volume of pond water can be harvested daily, depending on the season and other factors. An additional advantage of this pond type is its less demanding maintenance, the possibility of enlarging the pond area by increasing the number of ponds. The ability to integrate with wastewater treatment processes is an additional benefit. Raceway ponds consist of one or more connected canals in the shape of runways with a depth from 15 to $30 \mathrm{~cm}$. The paddlewheel is commonly used to maintain the continuous flow of water through canals and the mixing of algae. 
The system is used to remain algae exposed to the sun and $\mathrm{CO}_{2}$ as much as possible and to prevent algae biomass from settling on the bottom. In the circular ponds, water is stirred by a centrally pivoted agitator. Open-pond systems typically utilize natural light, so the cost of using artificial light is avoided. Compared to photobioreactors, open ponds have disadvantages such as low biomass yield, high harvesting costs, and the possibility of attack weeds, wild algae, microorganisms, and diseases, which all further reduce algae yield [29]. A high rate of water evaporation resulting in a high water footprint $[30,31]$. Two factors that enhance water loss by evaporation are temperature and wind speed. Thus, open-pond algae farming is suited only for areas with low-cost water [32].

Another algae cultivation system is based on closed glass containers called photobioreactor, as depicted in Figure 1. Different photobioreactor designs are applied, like flat panel, vertical column, tubular and hybrid systems [33]. They are made in the form of plastic or glass bags, containers, or towers. The high yield of algal biomass is obtained in bubble columns and airlift photobioreactors. The main objective of photobioreactor development is to maximize algae growth through optimal light supply through thin layers of microalgae suspension. Sometimes artificial light is used to increase yields, and some manufacturers rely solely on artificial light [8]. The use of artificial light often causes complex structures, a considerable number of surfaces with the resultant high sensitivity to pollutants, and high energy consumption for algae production. To date, commercially production in photobioreactors uses strains from only a few microalgal groups: green algae, dinoflagellates, and treustohydrides. One of the essential advantages of a closed algae farming system is the ability to create better, more controlled conditions for the growth of certain types of algae that cannot be achieved in outdoor ponds. Moreover, it can prevent or at least reduce the invasion of harmful algae and zooplankton that affect the yield of useful algae [8]. In addition to these advantages, the major disadvantage of photobioreactors is high investment cost $[34,35]$. Other disadvantages include difficulties with scaling-up, overheating, oxygen accumulation, bio-fouling, and cell damage over time [9].

There is also an alternative approach to growing algae in the dark, known as heterotrophic fermentation. Although photosynthesis is based on $\mathrm{CO}_{2}$ and light to meet the organisms' needs, another source of carbon has to be added to heterotrophic cultivation. Many organisms have developed mechanisms for the assimilation of carbon sources other than $\mathrm{CO}_{2}$. The ability to grow on sugar or acetate allows these organisms to survive even in dark conditions. In the mid-1990s, the heterotrophic algae production technology for Chlorella production was developed in Japan. Heterotrophic microalgae can take carbon and nitrogen from a variety of sources, but inexpensive materials such as inedible lignocellulosic feedstocks are preferred. The most cost-effective sources of nitrogen are ammonium or nitrates. The transition to heterotrophic production leads to a significant increase in volumetric production rates. While photobioreactor dries mass concentrations with peak values only slightly above $3 \mathrm{~g} / \mathrm{L}$, the heterotrophic processes easily reach ten to twenty times higher cell densities. Pankratz et al. [36] think that by applying photobioreactor technology, over five years, it is possible to increase the average biomass productivity from 5 to $8 \mathrm{~g} / \mathrm{L} /$ day.

When considering the algal biodiesel production, an important aspect is a yield obtained from algal biomass (Table 2).

Table 2. The yield of biomass and oil from different species of algae.

\begin{tabular}{|c|c|c|c|c|}
\hline Microalgae Species & $\begin{array}{l}\text { Lipid Productivity } \\
\text { (g/L/day) }\end{array}$ & $\begin{array}{l}\text { Lipid Content } \\
\text { (\% Dry Weight } \\
\text { Biomass) }\end{array}$ & $\begin{array}{c}\text { Biomass } \\
\text { Productivity } \\
\text { (g/L/day) }\end{array}$ & Reference \\
\hline Chlorella vulgaris & 0.1837 & 32.5 & $0.2341-0.5322$ & (Deng et al., 2018) [37] \\
\hline Chlorella vulgaris & 0.0421 & 47.53 & - & (Ye et al., 2018) [38] \\
\hline Chlorella vulgaris & 0.300 & 31 & 0.71 & (Pribyl et a., 2012) [39] \\
\hline Desmodesmus sp. $S 81$ & 0.01983 & 48.41 & - & (Zhang et al., 2016) [40] \\
\hline Nannochloropsis oceanica & 0.05691 & 46.14 & 0.91 & (Meng et al., 2015) [41] \\
\hline Parachlorella kessleri & 0.590 & 66 & 0.82 & (Takeshita et al., 2018) [42] \\
\hline Parachlorella kessleri & 0.500 & 25 & 0.64 & (Li et al., 2013) [43] \\
\hline Chlamydomonas reinhardtii & 0.08092 & - & 3.3 & (Shin et al., 2019) [44] \\
\hline Scenedesmus quadricauda & 0.13955 & 38.61 & 0.3614 & (Song and Pei, 2018) [45] \\
\hline
\end{tabular}


The presented results refer to laboratory research. In real conditions of algae cultivation, it is impossible to maintain ideal conditions like in the laboratory, so the realistically achievable results are much lower [46]. Biomass productivity can vary by more than one order of magnitude depending on location, farming system, and algal species. The efficiency of converting sugar into algae biomass is from 0.2 to $0.3 \mathrm{~g}$ of the lipid per gram of sugar to produce cells with high lipid content, usually with over $50 \%$ fat. The cultivation of heterotrophic microalgae typically takes place under strictly sterile conditions. Costs of contamination control or strict sterile farming can amount to $20-30 \%$ of production costs.

Recently, there has been growing attention to a combination of heterotrophic and photosynthetic production (mixotrophic production) as a way to increase production in photobioreactors [45]. While most manufacturers have focused solely on open-pond systems or only photobioreactors, some manufacturers have sought to combine the benefits of separate systems. This kind of algae cultivation that combines two or more of these systems is called a hybrid system. These may be small or more significant photobioreactors used in combination with outdoor ponds.

Recently, the possibility of connecting the process of wastewater treatment and algae cultivation into one integrated system is being considered. In such a system, algae would take nutrients and $\mathrm{CO}_{2}$ from wastewater for their growth and at the same time decompose unwanted and toxic substances. Algal biomass from such a system can be used to produce methane, fertilizers, and liquid fuels [8].

Another alternative approach to obtain algae biodiesel has attracted public attention. It is about the ability of some algae to continuously secrete oil into the medium in which they are grown instead of being stored in their biomass. Such a cultivation process requires a smaller amount of algal biomass and eliminates energy-intensive processes of algae collection and processing.

One new concept for enhancing algae harvesting and biofuel production is based on marine algae and fungi from the soil [47]. These fungi are spread throughout the yards and are not toxic, but they are not edible either. When the algae are in the same space with the fungi, they attach to them, creating large masses by bio-flocculation. When living symbiosis, they produce more oil than if farmed separately. The cost of collection is less because large masses of algae and fungi can be collected by cheap tools, such as a dense screen. This concept reduces the cost of farming and harvesting and increases productivity. These two factors are critical in determining the price of algae biodiesel. Algae, nannochloropsis grade, and fungi, Mortierella elongata, provide oils that can be used for various purposes, such as components of passenger car biofuels and omega-3 fatty acids that have a beneficial effect on human health. Within these algae farming systems, there are still many opportunities for innovation and improvements.

An alternative approach to increasing biomass yield is mutagenesis. Mutagenesis of Nannochloropsis oceanica increased yields and biomass growth rates by $19 \%$ and $6 \%$, respectively. Besides, lipid production increased from 211 to $271 \mathrm{mg} / \mathrm{L} / \mathrm{d}$ which is an increase of $28 \%$ [48].

Another alternative strategy is algae-bacteria co-culture. For example, the maximum biomass yield, lipid content, and lipid productivity of Chlorella vulgaris co-cultured with Mesorhizobium sangaii were $1.5,2.2$, and 3.3 times greater than by applying pure algal culture [49].

\subsection{The Production Process of Biodiesel from Algae}

The cycle of growing algae is very short (one to ten days), which allows for several harvests. This means that the yield of algal biomass is much higher compared to conventional crops, which further allows the production of a hundred times more oil than crops such as oilseed rape and soybeans [8].

After the growing cycle following harvesting: Applied harvesting technology depends on the type of algae grown and includes two major processes, namely collecting and algal biomass concentrating. Separation of water content is related to this biomass collection for further process of biodiesel production. The process involves two specific steps: 
1. Separation and thickening of microalgae from bulk suspension by micro strainers, by electrophoresis process, and by sedimentation, flotation, and flocculation;

2. Dewatering the microalgae slurry, applying filtration, or centrifugation [34,50].

The first step taken in algae collection is to carry out a screening process or filtration. Micro strainers and vibrating screens are standard screening devices used. The high harvesting rates and removal efficiencies of $95 \%$ could be achieved by using vibrating screen filtration [51]. For concentration improvement, various centrifugation systems are in use, like the solid ejecting disc, solid bowl decanter, and hydro-cyclone. Centrifugation represents the fastest method with biomass recovery up to $95 \%$ under optimal conditions, so it is preferable over other methods [52].

For large algae systems (closed photobioreactor), it takes $73 \mathrm{~kg}$ of water to process $1 \mathrm{~kg}$ of algae biomass, which requires high-energy consumption. Applying flocculation reduces energy consumption. Flocculation involves several complex processes: first, the unstable impurities of colloid when neutralization, and the formation of aggregates; second, the adsorption of organic matter by the aggregate through a bridging process; finally, particle aggregates are removed by sedimentation, filtration, and sweeping [53].

Several flocculation techniques can be used like chemical flocculation, auto flocculation, inorganic flocculation, electrolytic process, etc. [54]. For large-scale plants, harvesting by a chemical coagulation-flocculation method is too costly. This method has another disadvantage that influences its quality, namely the difficulty in removing the separated algae from excess chemicals. Disruption of $\mathrm{CO}_{2}$ into the algal system is a solution to this problem, which causes autoflocculation, where the algae flocculate by themselves [51].

In the flotation process, the air bubbles attach to the mass of algae and lift them to the surface of the fluid where they are easier to collect. After concentrating the algae suspension on $5 \%$ to $15 \%$ of dry matter, further slurry dehydration is needed to go to the following step of the production of biodiesel $[8,34]$. A significant energy amount is required for drying of algal biomass, amounting to $11.22 \mathrm{MJ} / \mathrm{kg}$ [55]. Therefore, drying is a significant economic concern because the energy required to dry algae can account for the largest share of processing costs. Removing the moisture content from the algal biomass is necessary because moisture interferes with further processing steps, such as lipid extraction and transesterification.

Many different dehydration techniques can be utilized for drying algae suspensions such as sun drying, freeze-drying, flashing drying, rotary drying, spray drying, toroidal drying, and fluid bed drying [34,56-58]. All particular technologies of thickening and dewatering algal slurry have different characters. The microalgae strain, size, morphology, and composition of the medium used for cultivation, influence the effectiveness of these technologies.

It is essential to analyze all available technologies before selecting which one to apply [59].

The dehydration of biomass is followed by lipid extraction from algae biomass. The process is much more demanding than oil extraction from terrestrial cultures. The solid wall of algal cells is the reason for the problematic release of lipids. The extraction of lipids from the mass of algae is usually done by a mechanical process (expeller press) or by chemicals and solvents.

The application of an extrusion press is a simple and efficient process of mechanically crushing algae cells to obtain the oil. The applied pressure should not be too high, as there is a drop in lipid quality. Other mechanical techniques in use include Bead beating. Application of chemical solvent for extraction of algal lipids, like n-hexane, methanol, and ethanol, seems to represent the most proper method, as it is valid and widely used in laboratory research (Folch method is the most popular). Nevertheless, the efficiency of this method highly depends on microalgae strains [60]. By the two-step process, saponification and esterification (homogeneous catalyst method, the efficiency of lipid conversion to biodiesel can be increased to $90 \%$.

However, before applying the chemical solvent extraction on a commercial level, several facts need to be considered: 
- A large amount of chemical solvent is required for efficient lipid extraction.

- The problem of solvent toxicity and safety should be addressed.

- Additional energy is required to recover the solvent.

- Wastewater treatment is required which is an additional cost

Other technologies that aim to enhance the algae lipid extraction like autoclaving [29], supercritical $\mathrm{CO}_{2}[30,32,61]$, ultrasonication [29,34,50], microwave-assisted extraction of lipids from microalgae [54], switchable solvent extraction [56], vacuum shelf drying [57], electroporation technique, and osmotic technique [58] are still in the development phase. Therefore, they need further improvement before being commercially implemented. To eliminate the energy consumption for the dehydration of algae biomass from the slurry, the technology of oil extraction from wet algal biomass has been developed. Samori et al. [59] investigated a novel extraction method that used interchangeable polarity solvents for lipids extraction from diluted algal cultures. The efficiency of this method is about $70-80 \%$. Advanced technologies for extract oil from algal biomass have been described in detail by $[60,61]$.

The biodiesel production system is shown in Figure 1. Arrow widths are proportional to mass flows.

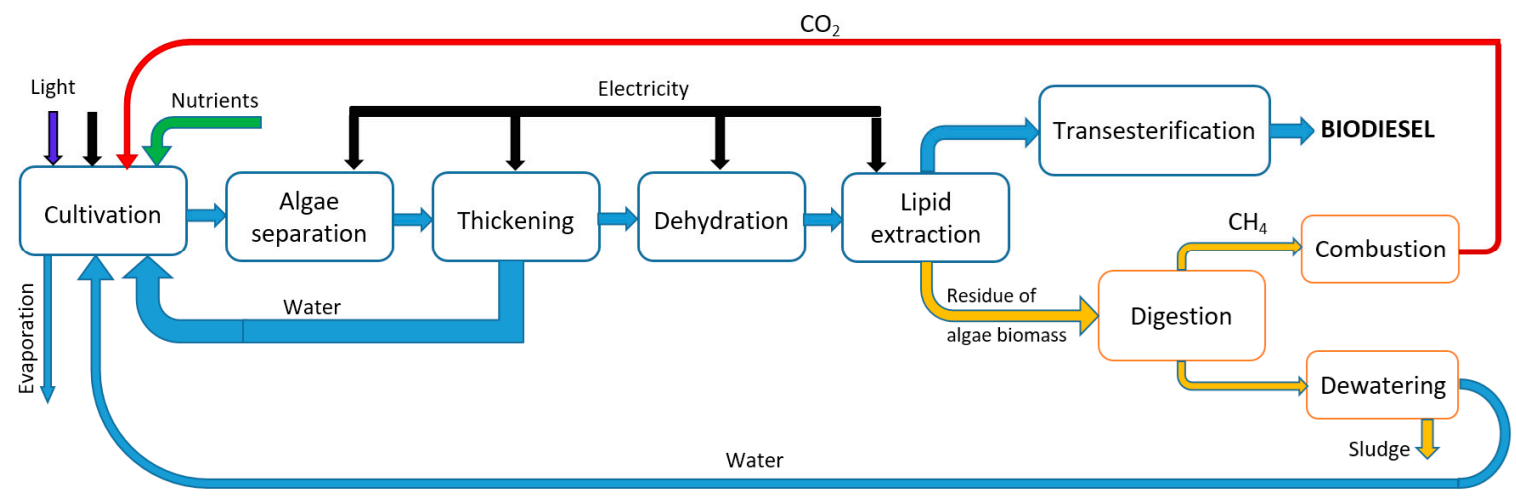

Figure 1. Scheme of the biodiesel production system (adapted from Clarens et al., 2011 [62]).

\subsection{Production Cost Analysis}

The cost of farming algae for biodiesel production varies significantly from research to research. The production cost of one liter of oil varies from $\$ 0.43$ to $\$ 24.60$, making it challenging to predict biodiesel prices in the future [63]. Algae biodiesel production technology is still under development, and prices are considerably higher than competitors in the market. Considerable effort has been placed into automating the production system to cut labor costs. If the price of crude oil rises and technological advances are made in the production of algae biodiesel, the biodiesel price in the future could compete with the price of conventional diesel [63]. Algae biodiesel production has increased since 2010, but low oil and natural gas prices have slowed further development [63]. The high costs of growing and harvesting algal biomass represent a significant barrier to cost-effective biofuel production. Harvesting represents $20 \%$ to $30 \%$ of the production costs of biomass [64,65]. The high cost of harvesting is due to the small concentration of microalgae in the water $[64,66]$.

Open-pond farming systems may be a more economical option for mass production of algae, but low biomass productivity and high water consumption further increase the operating costs $[63,67]$. The biomass production depends on the water speed in the channel. Low water speed gives laminar flow and low pond productivity. If the speed of water increases, so does productivity, but the power to run the paddlewheel increases cubically. This condition is especially pronounced for water velocities greater than $30 \mathrm{~cm} / \mathrm{s}$, which is especially evident in the increased energy costs. Closed photobioreactors, however, have higher biomass productivity and less contamination, but capital and operating costs are high. The highest share of energy consumption during the cultivation phase relates to the transport of media in the PBR and overcomes the friction loss. It is therefore unclear whether PBRs can become competitive with open-pond systems [68]. 
Most studies agree that the production of algal biodiesel is an energy-intensive process $[9,62,69]$. Thus, the current systems for algae biodiesel production are not energy sustainable, that is, they result in a negative energy balance [70]. As an indicator of the energy sustainability of a product's production, energy efficiency factor (EER) is used, which is defined as the ratio of energy produced and energy intake. EER higher than one indicates the net positive energy produced, and vice versa. The EER values are greater than one in the production of biodiesel from oilseeds [71], as depicted in Table 3.

Table 3. Energy efficiency ratio (EER) for biodiesel produced from the different feedstock.

\begin{tabular}{ccc}
\hline Feedstock & Technology & Energy Efficiency Ratio (EER) \\
\hline Jatropha & Linked transesterification and biogas production. & 3.34 \\
\hline Palm oil & Linked transesterification and biogas production. & 3.58 \\
\hline Marine microalgae & $\begin{array}{c}\text { Algae cultivation through PBR }{ }^{1} . \\
\text { Linked transesterification and biogas production. }\end{array}$ & 0.07 \\
\hline Freshwater microalgae & Algae cultivation in PBR. & 0.35 \\
\hline Freshwater microalgae & Algae cultivation in ORP ${ }^{2}$. & 1.46 \\
\hline & ${ }^{1}$ PBR-photobioreactor, ${ }^{2}$ ORP-open raceways ponds.
\end{tabular}

Furthermore, it was found that energy consumption in algae biomass production and processing is crucial in assessing the life cycle impact in all the categories evaluated. Especially, biomass drying and lipid extraction are the most energy-intensive processes, requiring the improvement of existing technologies or the adoption of new technologies to achieve a positive balance of energy and $\mathrm{CO}_{2}$. An increase in biomass productivity reduces the energy consumption in the production of biomass from microalgae, and this is also one of the areas where improvement efforts are being made.

Due to the lack of large farms, there are no large-scale farming data available. Laboratory data are often extrapolated, which is unrepresentative of a larger-scale application. Several researchers note that sustainable microalgae farming for large-scale biodiesel production is impossible in the short- and medium-term and further development is needed [72]. However, regardless of the required period, a key factor is minimizing production and maintenance costs, along with maximizing production [73].

The significant barrier to the market of algae biodiesel is the high cost of algae growing and harvesting [74,75]. According to Reference [76], farming and harvesting account for 50\% to $65 \%$ of the production cost. Oil extraction, pre-esterification, purification, and distributions would account for $15-25 \%, 10-15 \%, 2-3 \%$, and $2-3 \%$ of the cost, respectively [75].

The cost structure for algae farming in open ponds and photobioreactors is shown in Figures 2 and 3 (based on the investigation of $[35,63]$ ). The analysis shows that the capital costs for the case of open ponds are evenly distributed, while the cost of photobioreactors is dominated by the cost of construction ( $79 \%$ to $82.7 \%$ ).

There are many factors associated with algae production affecting cost-effectiveness: co-products, nutrients, harvest technology, biomass drying, and conversion. System design and algae species are essential but not the only factors.

In most cases, the cost of producing biofuels simply depends on the cost of biomass supply. Facilities for mass production of algae and energy use have yet been unbuilt. Therefore, with small amounts of algae that are produced, it is difficult to realistically evaluate the costs of producing more substantial quantities of biofuels from algae. 

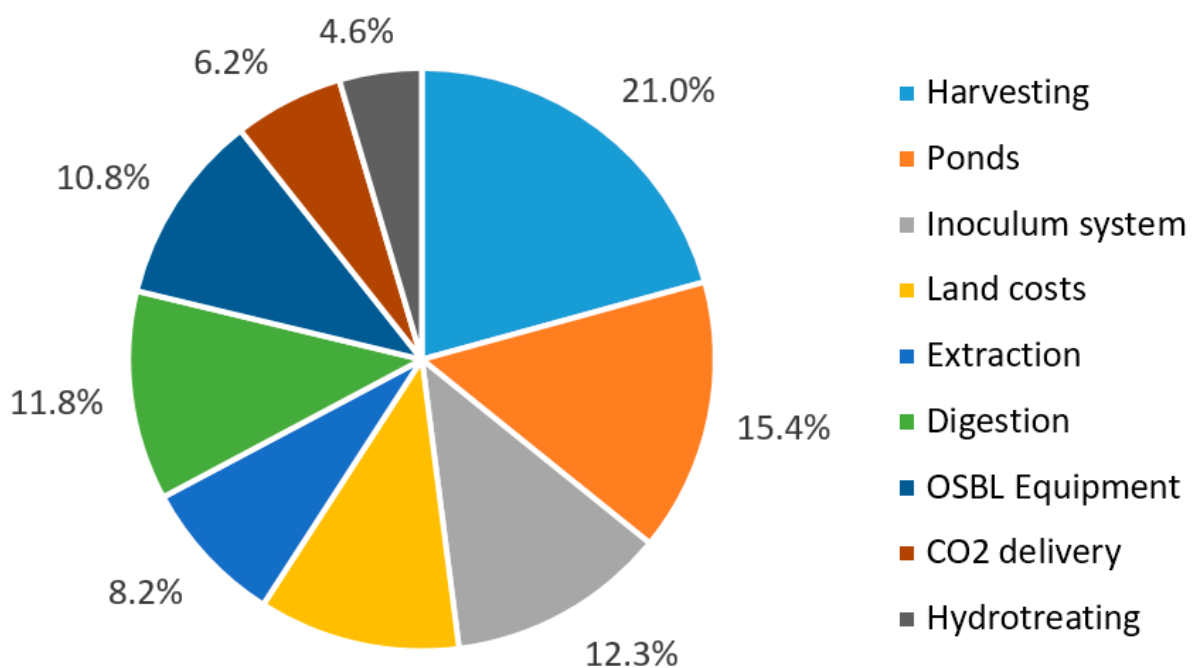

$11.3 \%$

Figure 2. Capital cost structure of open-pond systems.

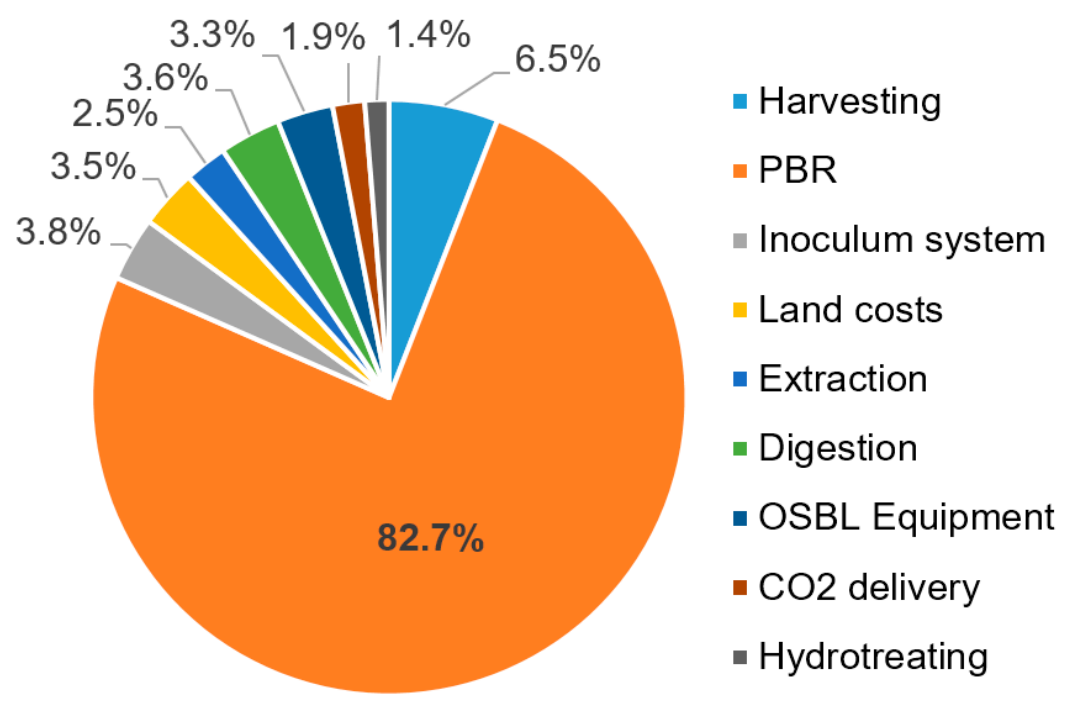

Figure 3. Capital cost structure of PBR systems.

The price for $1 \mathrm{~kg}$ of algae ranges from $\$ 16.4$ for open raceways ponds systems to $\$ 33$ for closed photobioreactors systems. Several cost estimates are available that look at the increase in size from today's ponds to several acre size ponds. One of those estimates is that for 1 acre of production, $1 \mathrm{~kg}$ of algae would cost about $\$ 11$, but costs could be lowered to about $\$ 4.4$ by increasing the sizes to 100 acres with today's state-of-the-art [63]. Although this estimate indicates a considerable cost-cutting, it is still too high to compete with existing terrestrial biofuels crops [63]. Tredici et al. [77] have analyzed T. suecica algae production on a scale of 1 ha. They obtained a cost of $\$ 15.8 \mathrm{~kg}^{-1}$ biomass produced. At the 100 ha scale, they estimated a cost of about $\$ 5.5 \mathrm{~kg}^{-1}$, which is much more than the $\$ 2 \mathrm{~kg}^{-1}$ that needed to make algae biofuel competitive with petroleum-derived diesel. According to the investigation of References $[63,67,78,79]$, prices of algae biodiesel grown in an open raceways pond (ORP) and a photobioreactor (PBR) can be shown (Figure 4). The average price of algae biodiesel grown in a photobioreactor is $\$ 4.93$, which is $66 \%$ more than in an open-pond system that is $\$ 2.97 \mathrm{~L}^{-1}$. 


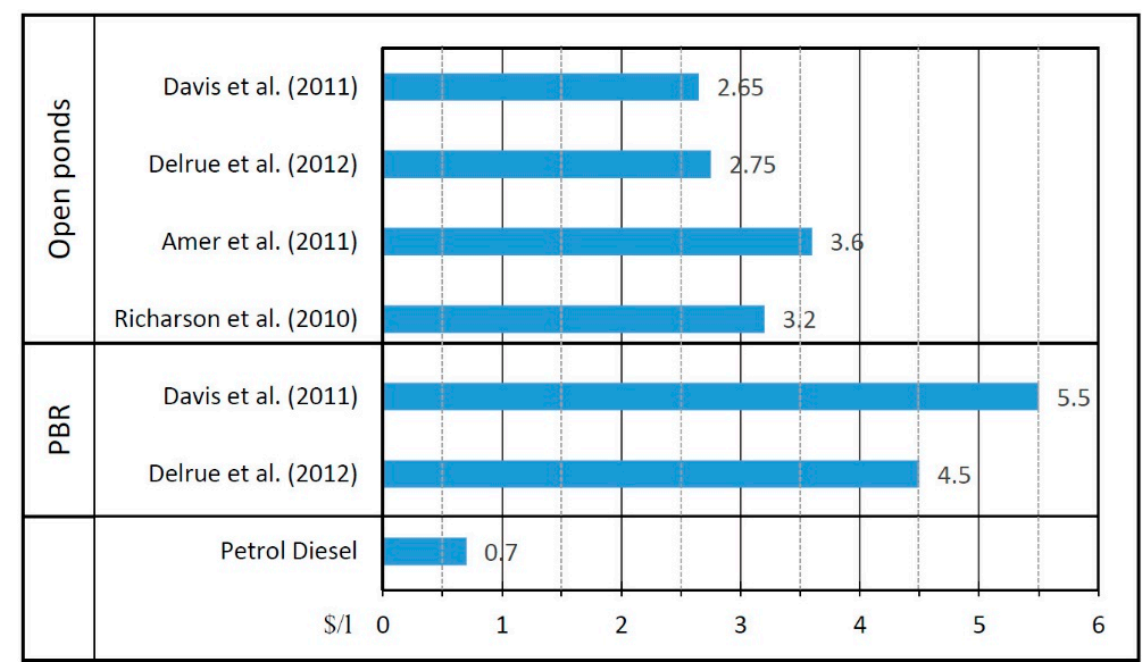

Figure 4. Prices of algae biodiesel obtained from different farming systems.

Although high biomass productivity and the cultivation of single-strain culture are enabled by using photobioreactor, cultivation is costlier than in open ponds.

In 2012, a continuous decline in biodiesel prices had been expected in the coming period [80]. Accordingly, the expected price of biodiesel in 2020 was about $\$ 1.5$ per liter, which unfortunately did not happen.

High competition with both systems is first and second-generation biodiesel. With soybean and oilseed rape of about $\$ 0.35$ per $\mathrm{kg}$, it seems that algae biofuel production is not currently profitable and will not be soon. The estimated selling price of biodiesel produced from waste frying oil, jatropha, and soybean was \$0.73/L [68], \$1.4/L [81], and \$1.35/L [82], respectively, which is higher than petrol-diesel (\$0.7/1), but lower than algal biodiesel. Pankratz et al. [36] consider that, over five years, it is possible to triple the size of PBR and increase the average biomass productivity from 5 to $8 \mathrm{gL}^{-1}$ day $^{-1}$. With a $25 \%$ reduction in capital investment, this would lower the algal biomass price below $\$ 0.2 \mathrm{~kg}^{-1}$.

\subsection{The Environmental Impact of Algal Biodiesel Production}

\subsubsection{GHG Emission}

From an environmental point of view, algae-produced biofuels must comply with international sustainability regulations like the EU Renewable Energy Directive, which provides guidelines for reducing GHG emissions. In this sense, biofuels from algae can contribute to reducing GHG emissions [80].

Azari et al. [83] analyzed the $\mathrm{CO}_{2}$ footprint of different algae farming systems. The results show that the lowest quantity of greenhouse gases in the amount of $67 \mathrm{~g} \mathrm{CO}_{2}$ eq./MJ of energy produced is associated with an open-pond system that uses wastewater. The reason is the use of solar energy for lighting and drying in an open pond. Heterotrophic culture (PBR) produces $89 \mathrm{~g} \mathrm{CO}_{2}$ eq./MJ. During heterotrophic farming, a continuous supply of $\mathrm{CO}_{2}$ has been eliminated that reduced GHG emissions. ORP system with water recycling has $95 \mathrm{~g} \mathrm{CO}_{2}$ eq./MJ, and the ORP system utilizing fresh water has $149 \mathrm{~g} \mathrm{CO}_{2}$ eq./MJ.

In the life cycle analysis (LCA) of biodiesel production, there are relatively large discrepancies in estimates of $\mathrm{CO}_{2} \mathrm{eq} / \mathrm{MJ}$ emissions of biofuel produced, with many results exceeding fossil diesel emissions [29]. The differences in the analysis are mainly due to the choice of diverse models and accompanied by considerable variations of microalgae treatment as well as the harvesting methods and fuel extraction. The results of these studies indicate the need to develop more effective and efficient farming and harvesting technologies to reduce GHG emissions in the LCA of algae biodiesel production. 
GHG emissions of advanced biofuel are depicted in Figure 5. The dashed lines show a 50\% to $60 \%$ reduction of GHG emissions to a reference value of fossil fuel of $87.1 \mathrm{~g} \mathrm{CO}_{2}$ eq./MJ [84]. Better conversion efficiency is the cause of the reduction in GHG emissions. The transesterification of micro-algae currently produces the highest emissions above $60 \mathrm{gCO}_{2}$ eq./MJ fuel.

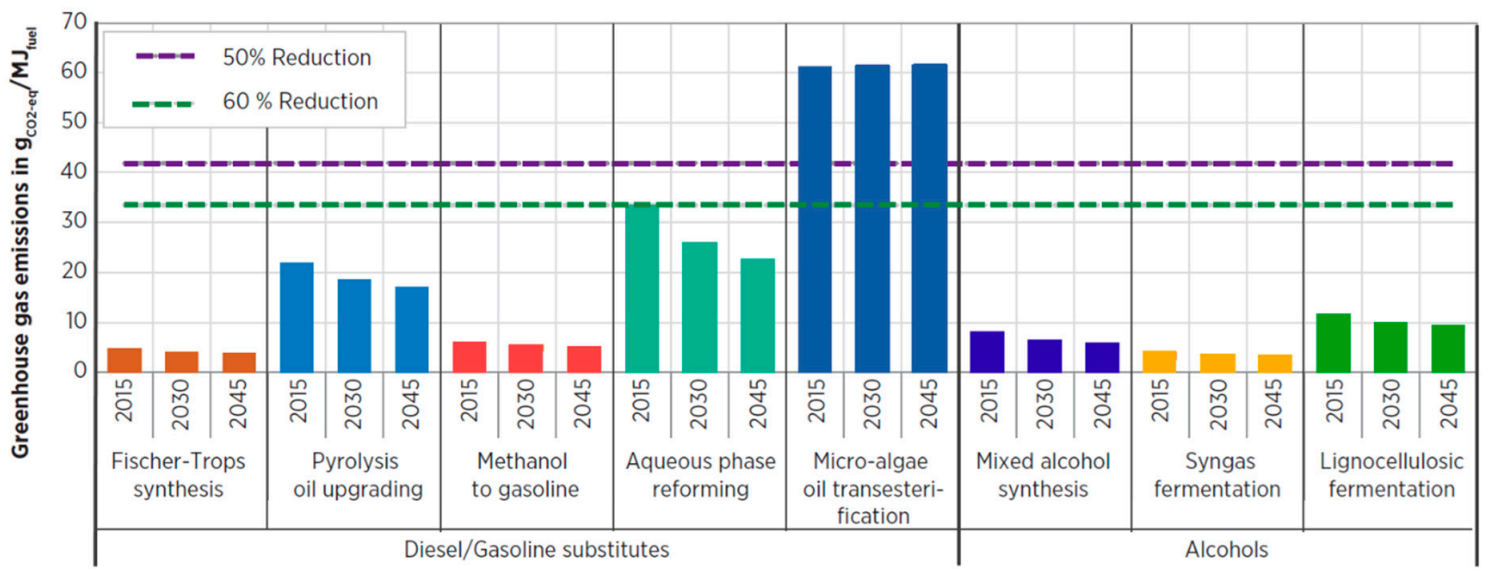

Figure 5. GHG emissions and emissions reduction comparison of advanced biofuel pathways [14].

If the intake of energy and nutrients is high, the $\mathrm{CO}_{2}$ emission for biodiesel production from open ponds may be comparable to the $\mathrm{CO}_{2}$ emission of conventional diesel. $\mathrm{CO}_{2}$ emission for biodiesel production from PBRs algae may exceed emission from oil shale feedstocks.

The production of $1 \mathrm{~kg}$ of dry algae biomass requires at least $1.83 \mathrm{~kg}$ of $\mathrm{CO}_{2}$, assuming a $50 \%$ carbon content of the algae. In reality, the amount of $\mathrm{CO}_{2}$ should be several times greater than the specified. The theoretical efficiency of $\mathrm{CO}_{2}$ absorption is in the range of $20 \%$ to $90 \%$, depending on operating conditions, while in actual conditions in open ponds, the efficiency is about 35\%. In PBRs, the $\mathrm{CO}_{2}$ absorption efficiency is higher, at about 75\% [85]. The need for a $\mathrm{CO}_{2}$ source (as well as the need for fresh water) influences the choice of algae farming sites. If $\mathrm{CO}_{2}$ from flue gas is to be applied, the algae farming location should be relatively close to the power plant or another significant source of $\mathrm{CO}_{2}$. Flue gases with a temperature between 20 and $35^{\circ} \mathrm{C}$, containing $15-20 \% \mathrm{CO}_{2}$ by volume, can be used for optimal algae growth. Since the temperature of flue gases from conventional power plants is close to $95^{\circ} \mathrm{C}$, they have to be cooled before use [86].

A large-scale algae farming can cause extensive environmental impacts. These impacts can limit the design and operation of the system. Water recirculation can reduce freshwater and nutrient consumption, but the risk of infection increases. Recycled water contains bacteria, viruses, and fungi in higher concentrations, as well as inanimate ingredients like organic and inorganic chemicals and the remains of algae cells. Algae farming can pose a potential threat to local and regional ecosystems. Exotic algae species discharged into the waterway can cause biological invasion and endanger the native species safety [87]. Perhaps the essential environmental aspect of microalgae production is water management. In any algae farming system, environmental monitoring plays an important role and remains a constant requirement.

\subsubsection{Land Use and Location}

The significant advantage of algae farming is the ability to exploit less valuable land, thus minimizing competition for food production. Due to the high production yields of microalgae, a smaller land area is required compared to conventional energy crops.

Topographic constraints reduce the availability of land for outdoor pond systems because the relatively flat terrain is required. The porosity/permeability of the soil also has an impact on the construction of the pond. Solar irradiation is one of the critical factors that influence algae growth and 
yields, and there should be small seasonal variations. Therefore, for practical purposes, warm places near the equator are most appropriate.

\subsubsection{Use of Nutrients and Fertilizers}

Nutrients requirement for the cultivation of algae not only depends on the species but also on the stress that is induced to stimulate the accumulation of lipids or carbohydrates. Basic nutrients are nitrogen, phosphorus, and potassium. Since the proportion of dry algae consists of approximately $7 \%$ nitrogen and $1 \%$ phosphorus, large quantities of fertilizers are required to produce biodiesel from algae. These quantities of fertilizers generally can be a problem. To date, organic and inorganic chemicals are widely used as nutrients for large-scale microalgae cultivation [88]. However, their application is expensive, and there are environmental risks that do not favor the mass production of microalgae biomass. LCA studies show that $50 \%$ of total energy consumption and GHG emissions relate to the application of inorganic fertilizers [89]. The production of inorganic fertilizers is energy very intensive because the production of 1 ton of ammonia ( $\mathrm{N}$-fertilizer) requires 37 to $40 \mathrm{KJ}$ of natural gas. The least fertilization requires oil palm plantations, i.e., $83-87 \%$ less than the farming of microalgae. For the cultivation of the jatropha, rapeseed, and sunflower, it needs $17-35 \%, 52-62 \%$, and $59-68 \%$ less fertilizer, respectively [71]. Ammonium nitrate as fertilizer has the most significant impact on climate change.

Taking into account that the wastewater contains a significant amount of nitrate and orthophosphate, the use of this media in the cultivation of algae appears as an acceptable economic alternative. However, respecting the fact that the mineral content in wastewater varies significantly on the location and season, it is difficult to rely entirely on this source of fertilizer.

The recycling of nutrients from wastewater may provide some of the nutrients needed, so the fundamental design of processes includes nutrient recycling as a fundamental aspect of system operation.

\subsection{Biodiesel Production from Algae in the World}

The global annual amount of algal biodiesel produced is tiny. The development of these fuels has been slowed by the fall of oil prices in 2014. This condition continued with the global economic crisis. Research indicates that the current production of algae biomass in Europe is negligible $(1.14 \%$ of world production). In Europe, algal biomass production has been stable since 1950, below $0.5 \mathrm{Mt}$. Algae production is mainly located in Norway, France, Ireland, Iceland, and the Russian Federation.

The prediction is that a technical production potential of 41 megawatts of algae biomass can be achieved by 2030 in Europe, with production costs less than $\$ 0.985 / \mathrm{kg}$ [82]. Only twelve EU countries are producing significant amounts of algae biomass. Spain has the highest potential for algae cultivation compared to other EU countries. Despite its great theoretical potential, algal biodiesel is unlikely to be competitive by 2030 or 2050 concerning fossil fuels [82].

In the California desert, a 0.8 ha (10 acre) pond is filled with saltwater and algae. This pond is one of several ponds where Exxon Mobil and Synthetic Genomics is trying to organize large-scale biodiesel production at competitive prices. In 2017, the partners announced that, by genetic engineering, they got twice the amount of fat compared to wild algae. They failed to increase their growth rate, and it remained the same. They are still working on the problem of algae productivity. Great efforts are being made to improve algae cultivation and collection efficiency. Exxon engineers are studying how best to mix the algae, so they get as much sunlight and $\mathrm{CO}_{2}$ as possible, both components necessary for algae growth, which requires a good understanding of photosynthesis. For the specified area of 0.8 ha $\left(40,470 \mathrm{~m}^{2}\right)$, it is possible to produce 0.8 to 3.6 barrels/day (137 L/day to $567 \mathrm{~L} /$ day) of biodiesel. With some assumptions about further improvement of algae farming, companies plan to produce 10,000 barrels of algae biofuel per day in seven years. This amount requires an area of 11,360 to 50,000 ha (which corresponds to an area of 5680 to 25,000 football fields). This capacity is very small compared to crude-oil production (10 million barrels per day). To be able to talk about significant production ( 1 million barrels per day), huge areas for algae cultivation are needed, 1,136,000 ha to 5,000,000 ha. 
Assuming that the depth of the pool is about $30 \mathrm{~cm}$, the water required for the specified area is from $3.4 \times 10^{9}$ to $15 \times 10^{9} \mathrm{~m}^{3}$ (authors' analysis).

Reliable and inexpensive water supply is one of the critical elements of the commercial production of algal biomass at lower prices [70]. Water should be added to ORP to offset evaporation, and cooling water is also required for some closed photobioreactor designs [90]. Water recycling after harvesting can contribute to a significant cost reduction. This returns some of the nutrients to the process, reducing fertilizer consumption [70]. Some researchers identify an opportunity for economical algae farming in link to the wastewater treatment process [91]. However, it should be borne in mind that in higher latitudes the use of microalgae in wastewater treatment is restricted by the short vegetation season, low air temperatures, and shorter day lengths in certain parts of the year [92].

A summary comparison of the characteristics of open-pond systems and photobioreactors is shown in Table 4, based on the data [93,94].

Table 4. Performances of raceway ponds and photobioreactors.

\begin{tabular}{ccc}
\hline Culture System & Raceway Ponds & Photobioreactors \\
\hline Required space & High & Low \\
\hline Area/Volume ratio $\left(\mathrm{m}^{-1}\right)$ & Low (5-10) & High (20-200) \\
\hline Water loss & $\begin{array}{c}\text { Very high, may also cause salt } \\
\text { precipitation }\end{array}$ & Low \\
\hline $\mathrm{CO}_{2}$ loss & High, depending on pond depth & Low \\
\hline Oxygen concentration & $\begin{array}{c}\text { Usually low enough because of } \\
\text { continuous spontaneous outgassing }\end{array}$ & $\begin{array}{c}\text { The closed system requires gas } \\
\text { exchange devices }\end{array}$ \\
\hline Light utilization efficiency & Poor & Excellent \\
\hline Temperature & Highly variable & Cooling often required \\
\hline Cleaning & None & $\begin{array}{c}\text { Required (wall-growth and dirt reduce } \\
\text { light intensity), but causes abrasion, } \\
\text { limiting photobioreactor life-time }\end{array}$ \\
\hline Contamination risk & High (limiting the number of species \\
that can be grown) & Low \\
\hline Biomass quality & Variable & Reproducible \\
\hline Biomass concentration (g/L) & Low, between 0.1 and 0.5 & High, generally between 0.5 and 8 \\
\hline Process control & Limited (flow speed and mixing) & Possible \\
\hline Weather dependence & High (light, temperature, rainfall) & Low \\
\hline Start-up & 6-8 weeks & 2-4 weeks \\
\hline Oparvesting efficiency & High & Very high \\
\hline
\end{tabular}

\section{Results and Discussion}

The SWOT analysis finds potential and favorable strategies attractive to stakeholders and decision-makers, including sustainability and product prospects. The critical components to be discussed about algae biodiesel production refer to diverse influential factors that can be grouped in technological, environmental, economic, societal, and political factors. The analysis of threats and opportunities is pertained to the present and, even more importantly, also the future environment.

Determining the importance of these factors by SWOT analysis gives a clearer view of the chances of success of large-scale algae biodiesel production. 


\subsection{Strengths}

\subsubsection{Technical}

Algae farming can take place throughout the year, and algae can be harvested daily, so the algae oil production is much higher than of ordinary crops. Because of the high production yields of microalgae, a smaller land area is required compared to conventional energy crops. Various biofuels like biodiesel, aviation fuel, ethanol, green gasoline, and methane can be produced from algae. These biofuels are non-toxic and biodegradable. Blending petroleum fuels with biofuel will improve lubrication quality and reduce the sulfur content in the resulting fuel.

\subsubsection{Environmental}

Any medium location and environment can be used to culture macro and microalgae, including fresh water, sewage plants, wastewater, brackish environments, marine, and uncultivated land.

Algae farming does not need pesticides or herbicides.

In farming microalgae, it is possible to connect wastewater treatment. Wastewater includes municipal wastewater from which phosphates and nitrates need to be removed before discharge into waterways.

Exhaust gases $\left(\mathrm{CO}_{2}\right)$ from power plants can be used for algae cultivation, thus contributing to the reduction of $\mathrm{CO}_{2}$ emissions.

The $\mathrm{CO}_{2}$ footprint for algae biodiesel is smaller compared to conventional diesel [14].

\subsubsection{Diversity in Resources Harnessing}

The species and strain that are being explored as potential biofuel cultures are numerous, providing genetic diversity. Different types of algae have different cultivation characteristics. Algae typically contain $20-80 \%$ oil that can be converted to various fuels. Genetic technology can be used to increase lipid content and biomass productivity and algal stability.

\subsubsection{Sustainable Developments}

Algae do not require quality soil for cultivation, and they do not compete with food.

\subsection{Weaknesses}

\subsubsection{Technical}

It is challenging to find a strain of algae with high biomass production and high oil content, that is cost-effective and suitable for the region in which it is grown, and that is not too difficult to harvest.

When using $\mathrm{CO}_{2}$ from the flue gases of power plants, there is a problem of toxic compounds in the flue gas such as NOx and SOx.

To cut operating costs, post-algae water recycling is often applied. However, reuse of growth media reduces algal productivity because of increased pathogen contamination and/or accumulation of metabolites of secondary inhibitors.

The cultivation of algae over a long period in almost saturated cultures leaves cell debris with a tendency to stick and foul the vessel walls. Such deposits are usually removed by peeling the surface; however, after several years of application, the glass surface is damaged. This reduces the optical performances of even the highest-quality glass.

The disadvantages of ORP are the low biomass yield compared to PBRs, high harvesting cost, and the possibility of contamination with fast-growing wild algae.

Topographic constraints reduce the availability of land for outdoor pond systems because the relatively flat terrain is required. On the other hand, PBRs have a disadvantage in high cost, dimensional limitations, and technical complexity. 
Most techniques of algae harvesting have drawbacks, such as low separation efficiency, high operational costs, and poor quality of the product. Mechanical separation of algae, such as filtration, sedimentation, and centrifugation, causes cell rupture and cell contents leaking, which can result in poor oil quality. When flocculation is applied, the high concentration of coagulants impact product quality. Although this improves the water footprint, there are side effects such as salt deposition on the surface of the bioreactors, leading to a reduction in their service life. Moreover, the salt in the final biomass is increased.

In the system of open ponds, there is a problem of poor efficiency of light utilization and of lower volumetric productivity. The contamination of algal culture by viruses, graders, protozoa, and insect larvae also reduces productivity.

\subsubsection{Economic}

Processing of microalgae to biodiesel or bio-crude oil is an extremely energy-intensive production [95]. Thus, the current systems are not energy sustainable for algae biodiesel production, that is, they result in a negative energy balance [68]. Collecting, concentrating, and drying causes high energy costs and the associated effects of greenhouse gases.

Harvesting by a chemical coagulation-flocculation method is too costly. This method has another disadvantage that influences its quality, namely the difficulty in removing the separated algae from excess chemicals.

The conversion of solar energy into organic energy remains low efficient despite the efforts of scientists and companies.

It is difficult to achieve high lipid productivity on a commercial level.

Production costs are still significantly higher than conventional fuels. It is crucial to cut the capital costs of several major components, like pond linings, photobioreactors, paddle wheels, recovery, and extraction devices.

In the last ten years, very little progress has been made in the commercialization of algae biodiesel. There are few commercial "algae farms", so there are no necessary data on large-scale algae farming.

\subsubsection{Environmental}

The use of biodiesel from algae instead of conventional diesel has a positive impact on the environment as GHG emissions are reduced. However, the production of biofuels from lignocellulosic material has a better effect in this regard. Furthermore, lignocellulosic materials reduce the potential conflict between land use for food production and energy. Lignocellulosic raw material requires less intake of fertilizers, pesticides, and energy and is cheaper than crops. Biofuels from lignocellulose have a favorable impact on the environment because they have a very small $\mathrm{CO}_{2}$ footprint. Production of diesel from forest residues by gasification and Fischer-Tropsch synthesis releases a $\mathrm{CO}_{2}$ emission of only $3.6 \mathrm{kgCO}_{2} / \mathrm{GJ}$ fuel, and the price of the produced fuel is $\$ 18 / \mathrm{GJ}$ fuel. Production of diesel from the agricultural residue by hydrolysis and aqueous phase reforming of sugars releases a $\mathrm{CO}_{2}$ emission of $25.2 \mathrm{kgCO}_{2} / \mathrm{GJ}$ fuel, and the price of the produced fuel is $\$ 45-\$ 86 / \mathrm{GJ}$ fuel.

Production of algae diesel via transesterification releases a $\mathrm{CO}_{2}$ emission of $32.8 \mathrm{kgCO}_{2} / \mathrm{GJ}$ fuel, and the fuel price is $\$ 24-\$ 318 / G J$ fuel [14]. Algae seem to be the most expensive feedstock, with the highest $\mathrm{CO}_{2}$ emission.

Water footprint in the production of algal biodiesel, without the water recycling, is as much as $3726 \mathrm{~kg}$ of water $/ \mathrm{kg}$ of biodiesel [96].

\subsection{Opportunities}

\subsubsection{Technical}

The production costs can be cut by using algal strains that have not to be stored in the photobioreactor for a long time. It can be developed effective and cheap lining to cover open ponds 
(e.g., durable and cheap materials that can withstand the open-pond conditions for a long time). Paddlewheel design can be optimized or inexpensive alternative mixing techniques can be developed.

Further research on metabolic pathways has been linking fertilizer input and nitrogen deficiency to optimize lipid content and productivity. There are advanced energy-efficient technologies for algae biomass separation like electromagnetic field or extraction by a solvent. It is also possible to use solar drying that can lead to energy savings. Solar water heating or direct solar irradiation could be used for algae drying [51]. Since solar irradiation depends on weather conditions, the main drawback of this method is related to overheating and unreliability.

Recycling water post-harvest, efficient strategies for nutrient recirculation, and light exposure are opportunities for cost reduction.

Heterotrophic and mixotrophic production is one option that can provide a significant increase in production volume.

With the development of PBR technology over five years, it is possible to increase the average biomass productivity from 5 to $8 \mathrm{gL}^{-1}$ day $^{-1}$.

The new concept for biofuel production based on two types of seaweed and fungi from the soil can reduce the cost of farming and harvesting.

If the anaerobic digestion of algal mass residues is connected to the biodiesel production system (see Figure 2), biogas, solid, and liquid digestate are created. The digestate can be sold as a fertilizer to improve the soil, which will increase the efficiency of the entire system.

\subsubsection{Environmental}

The blend of algae biofuel with fossil fuel will reduce the sulfur content and improve quality. In temperate climates, algae have cyclic production which affects the system and sustainability of biofuels. The biomass can be converted into commercially sustainable coproducts, such as degreased animal feed, and as fertilizer in agriculture. This can be an effective way to minimize waste and a cheaper way to get animal feed than that based on corn or cereals.

Algae use $\mathrm{CO}_{2}$ for their growth, which can be obtained from the flue gases of power plants and other sources, and which is usually released into the atmosphere. In this sense, subsidies, carbon trading, and carbon taxes in the future may have a notable impact on the profitability of algal biofuels. This policy can enhance the implementation of $\mathrm{CO}_{2}$ capture from power plants.

\subsubsection{Economical}

As mentioned above, the use of algal biodiesel as a fuel is at the forefront of the challenge of lowering the price of more economical biofuels. To increase the economic value of algae, it is also necessary to review the utilization of by-products produced from algal biodiesel production. Sometimes we ignore the economic value of this by-product, but often this by-product can provide a far higher value than the main product itself, the biodiesel. Moreover, much non-energy or high-value products can be extracted from algae, which are considered commercially valuable [97]. The economic viability of an algae biodiesel industry, which has not been promising, might become feasible if it takes into account the economic value of this by-product. Valorization of many by-products in algal biodiesel production could improve production economics. However, it is significant that plenty of companies with biofuel production shifted to producing high-value products from algae, such as food supplements and cosmetics.

Algae are composed of three main compounds, namely protein, carbohydrates, and lipids. These three compounds have been proven to be used as high-value biomaterials in the industry. Algae can produce various products, depending on the processing method. In the chlorination process, green algae that live in rivers and lakes can be used as precursors in making halobenzoquinone (HBQ) disinfectants [98]. 
In the process of biodiesel production, crude glycerol is formed in a significant amount from $8 \%$ to $10 \%$. It can be applied in the production of hydrogen, biopolymers, ethanol, and fuel additives through the process of gasification and pyrolysis [99].

In the last few years, a biorefinery system has been created that produces biodiesel fuel and various other products. The application of modern technology that uses supercritical extraction can provide more results, lower costs, and ease of operation [100]. The feasibility of a biorefinery that produces multi-products will undoubtedly increase the feasibility of using algae as biodiesel fuel.

Algae need nutrients (mainly nitrogen and phosphorus) for their growth that are also found in wastewater. The use of wastewater for algae farming provides a nutrient for algae, and at the same time, wastewater treatment is performed. By combining these two processes, it is possible to reduce costs and thus make algae production more competitive. Nevertheless, it should be remembered that the composition of nutrients from wastewater change over time, making it difficult to use [101].

\subsubsection{Social}

Job creation is often seen as a significant benefit of the algal biofuel supply chain [102]. Many companies that produce algae biofuels already have a significant number of employees in their plants. This should include indirect employment in companies that supply resources for the production of algae (nutrients, $\mathrm{CO}_{2}$, and coagulants), which produce and maintain various components of the plant (pipelines, valves, pumps, screens, and measuring instruments).

\subsubsection{Political}

In general, each region or country has played a role in renewable energy in its long- and short-term energy planning to secure a sustainable and competitive source of energy. The production and use of biofuels are primarily governed by national policies aimed at reducing dependence on fossil fuels while reducing the impact of GHG emissions.

In 2017, Europe was one of the leaders in the global algae-produced-biofuel market. Europe has a significant demand for algae biofuels due to government regulations. Germany has contributed most to this region, thanks to the presence of leading car manufacturers. The European Union has put in place different policies to determine the level of application of renewable energy sources. The Renewable Energy Directive (RED) sets a mandatory target to apply at least $10 \%$ of biofuels in transport by 2020 . Although the share of biofuels used for transport in the EU rose from $7.4 \%$ in 2017 to $8.1 \%$ in 2018, this is below the EU target [103]. This directive is expected to trigger the market for algae biofuels in Europe. European Parliament has restricted the production of crop-based biofuels to support algae and other inedible biomass production.

According to RED, the European Commission requires the use of biofuels and bioenergy to achieve the climate and energy targets to be fulfilled in the EU by 2020. To ensure the sustainable use of these bioenergy resources, RED has established criteria and targets for achievement. According to RED, it is necessary to achieve a minimum threshold for reducing GHG emissions from the use of biofuels by $35 \%$. The targeted reduction in GHG emissions from biofuel substitution was a minimum of $50 \%$ in 2017. The target of GHG emission reduction was set at $60 \%$ in 2018.

The BioFAT project, coordinated by Portugal, aims to demonstrate algae farming on an area of 10 hectares and the production of biodiesel and ethanol. In this project, carbon dioxide will be produced from some fermentation industries. At this time, two pilot plants have been built, namely in Italy and Portugal. In the United States, the national standard organization of this country has succeeded in raising the quality of renewable fuels and increasing the types of fuels included in this category. The country has also targeted to produce renewable fuels of 36 billion gallons by 2022. The commitment of the Chinese government to the application of renewable fuels can be seen from their five-year plan, which has entered the third stage. Quite a lot of research has been carried out by involving research institutes, companies, and universities, particularly in developing biodiesel algae. The government has funded quite a lot of research to harvest microalgae and produce it into fuel, and develop more 
appropriate and economical technologies. South Korea is sponsoring four major R\&D projects, starting in 2019. The Sea and Seaweed Biomass Development Project focuses on the production of clean energy from seaweed biomass. Global Frontier project has incorporated the algae technology, which explores mass production of the biomass, and another project to explore technology for $\mathrm{CO}_{2}$ capture and storage.

The program for utilizing biofuels derived from algae was also developed in Japan. This country concentrates on the production of jet fuel, which began commercialization in 2020. Likewise, Taiwan already has a law on the use of renewable fuels in 2009. The field of research developed mainly on the selection of microalgae, breeding types, and extraction of lipids. Two enterprises investigate $\mathrm{CO}_{2}$ emission reductions by feeding the algae with fumes. The Energy and Environmental Research Laboratory also study topics relevant to algae biofuel production. In India, the National Biofuels Policy supports the funding of all generation biofuels research, which explores research such as sewage treatment of algae and biofuels from phytoplankton algae products. Many universities are engaged in this kind of research. Brazil is known for producing cane bioethanol. This country also supports research in algae biofuels. The government institutions collaborate with university and private sectors in researching algae biofuel production.

Algae biodiesel can play a significant role in improving energy security in transport. The production of jet fuel from algae can be of great importance in aviation. Aviation needs liquid fuels, and therefore cannot use many other alternative energy sources. It is strategically important to provide sufficient quantities of fuels for the air force, and especially for the military air force. One way to ensure this is by developing local fuel supply chains on all continents. These fuel supply chains may also involve the production of aviation fuel from algae with the aim of reducing fuel imports [104]. Moreover, bio-aviation fuel (bio-jet fuel) is recognized as a short-to-medium-term solution toward an overall reduction of the sector's GHG emissions.

\subsection{Threats}

\subsubsection{Technical}

There have been discovery and competition of other renewable fuels and energy. The primary competitors come from battery-powered electric vehicles and hydrogen-electric vehicles. The number of patents can also be a good indicator of the development of a particular area. From analyzing both areas and searching the patent databases, the authors concluded that the number of patents related to the application of hydrogen in vehicles is much higher than the number of patents related to the algae biodiesel.

Future demand is a potential threat and will harm the industry if interest and demand for biofuels recede in the future.

Large quantities of fertilizers are required to produce biodiesel from algae. These quantities of fertilizers generally can be a problem.

\subsubsection{Economic}

The market acceptance and economic viability of algal biodiesel are still uncertain. Biogas production from algae seems to be more economically feasible than bioethanol or biodiesel. Probably, this is because the entire biomass of algae is used in biogas production. In contrast, the production of bioethanol and biogas requires a specific component of algae such as carbohydrates (for bioethanol and lipids (for biodiesel), which should be extracted or pretreated before the production of biofuels. This will increase the cost of production [33]. The persuasive argument from Jard [105] is that the production of biogas from algae is closed to commercialization, indicating that complex carbohydrates could be converted to biogas. Another study also showed that the production of biogas from algae had energy security advantages and greater GHG as compared to liquid fuels [106]. 


\subsubsection{Market}

Many governments have concluded that fossil fuels are unsustainable resources. Resource depletion occurs, and carbon dioxide concentration increases. Research has shown that producing algal biodiesel is a viable alternative. Research also shows that the percentage of diesel vehicles sold will fall in the European Union by 2030. Diesel companies claim a diesel market share in European markets has already fallen from 52\% to 45\% between 2015 and 2017 [107]. European Union regulations also set targets for air quality, the condition of which is continuously monitored and, where necessary, corrected. The air quality directives set standards for local air quality (limit values and target values, which should not be exceeded for a range of air pollutants). For nitrogen dioxide specifically, the limit values prescribed in most Member States and more than $130 \mathrm{EU}$ cities have been consistently exceeded for many years, so changes are needed [107]. One of the benefits of farming algae is its high growth rate, the produced materials are non-toxic and biodegradable, and the use of biofuels contributes to reducing carbon dioxide concentrations. Therefore, exploring the possibility of producing biofuels from algae biomass has attracted attention.

Energy Performance of Buildings Directive 2018/844, Article 8, discusses the technical systems of buildings and indirectly promotes electric vehicles and states the following: "With regard to new non-residential buildings and non-residential buildings undergoing a major renovation, with more than ten parking spaces, Member States shall ensure the installation of at least one recharging point within the meaning of Directive 2014/94/EU of the European Parliament and the Council and ducting infrastructure, namely conduits for electric cables, for at least one in every five parking spaces to enable the installation at a later stage of recharging points for electric vehicles..."

This approach, to tackling $\mathrm{CO}_{2}$ over-concentration in the air due to fossil fuels, does not favor the development of technology related to the production and cultivation of algae, for the use of alternative biofuels. Biodiesel has no market advantage over electric cars and the use of electricity as a vehicle charging resource. Biodiesel produced from algae is globally environmentally friendly.

However, the use of electricity to power the vehicle is more accessible than algae biodiesel, and local environmental pollution is low.

The Communication "Towards an Integrated Strategic Energy Technology Plan" stresses the need for Europe to be competitive in the battery sector, which will support the further development of electric vehicles (European Commission, 2015). High prices for electric vehicles, mainly due to the high cost of batteries, remain a barrier to their widespread use. Nevertheless, recent research shows that battery costs will fall faster than predicted. Passenger cars are the front runners in accepting electric motors; although, since electric vehicles are not yet competitively priced compared to fossil fuel vehicles, co-financing from public authorities is needed. The car market is slowly changing: New electric models are coming to the market, and the sales of electric vehicles are growing. Besides this, the density of the car charging network is improving.

The change in the market is also compounded by the fact that China has increased the adoption of new Phase-6 emission standards under its anti-pollution "Blue Sky Defense" plan. Following the example of some cities in Europe, China plans to begin banning the production of diesel engines. Restrictions on the sale of gasoline vehicles have already been introduced in some cities in China. In 2018 Shenzhen and Shanghai together have sold more than 165,000 electric vehicles, which are positioned in first place in the world. That is more than Norway and Germany together. Although the market share of electric vehicles is only $2 \%$ in 2018, it is expected that in Europe by 2030, and globally by 2040 , their share will be around $50 \%$. Generally, electric vehicles are very efficient and use less energy per kilometer distance than combustion engines.

Therefore, it is expected that electricity has a more prominent part in the decarbonization of the transport system and lowering noise from vehicles. Greater use of electricity is a major driver of energy transformation. The transition to electromobility contributes significantly to this. Thus, in 2018, sales of electric vehicles (EVs) (battery and electric and hybrids) exceeded 2 million units, an increase of $58 \%$ over the previous year (InsideEVs, 2019). In Norway, in 2018, almost half of all passenger cars sold 
were electric (Electrek, 2019). Globally, about 5.6 million battery-electric passenger cars were in use by the end of 2018. The transition to electricity has also affected buses, especially in China, where in some cities most public buses are powered by electricity. For example, there are over 16,000 electric buses on the road in Shenzhen (IRENA, 2019) [16].

Electricity consumption in transport could reach $43 \%$ of the sector's energy by 2050 . In the same period, about $70 \%$ of all cars, buses, trolleys, and trucks could be powered by electricity. Of this, about $8 \%$ is projected to be powered by hydrogen and other renewable transport fuels. Advanced liquid biofuels for aviation, heavy cargo and, maritime transport will gain importance and will need to increase their production [15].

\subsubsection{Environmental}

The perception of algae is sometimes generally negative, especially in Western countries. Mentioning algae often creates an image of green swamps or toxic algae flowers [108]. This perspective is heightened if the harmful effects of algae occur in the region, and the media overemphasize such phenomena, as in the case of Lake Erie, which suffocates every summer in thick layers of algae, most of which are poisonous.

Algae biomass residues must not be carelessly disposed of in the environment as contamination may occur. From these residues, a high-quality protein meal for animals can be produced. However, if the microalgae are from wastewater, algae residues should not be used to feed fish or livestock. Extreme weather conditions can affect algae crops and conventional crops differently but lead to potential crop loss.

Microalgae farming can be a potential threat to local and regional ecosystems. Exotic algae species discharged into the natural environment can cause biological invasion and endanger the native species safety.

\subsubsection{Political}

Advanced biofuel production is usually costlier than for fossil fuels and biofuels of the first generation. Therefore, the policy mechanisms of the government are essential for the advanced biofuel market. The EU has no policy to encourage biofuel use after 2020, and its introduction is still unclear. Furthermore, mechanisms by 2020 to encourage the use of advanced biofuels have not been effective in raising investment.

The current biofuel policy is focused on road transport and successfully supports the production of alcohols like ethanol, but not diesel and jet fuel production.

\section{Conclusions}

In the past decade, algae biofuels have attracted the attention of the public and the scientific community for environmental and other reasons. Various factors produce a beneficial and negative impact on the further development of this area. The results of the SWOT analysis indicate essential strengths, weaknesses, opportunities, and threats.

1. Essential strengths are as follows:

- Algae productivity is higher compared to most effective crops.

- A large number of algae species can be farmed.

- The $\mathrm{CO}_{2}$ footprint of algae biodiesel is smaller than conventional diesel.

2. Essential weaknesses are as follows:

- Biodiesel production from algae is an extremely energy-intensive process that, in some cases, results in a negative energy balance.

- Production costs are significantly higher compared to the production of conventional diesel. 
- The water footprint is large.

3. Essential opportunities are as follows:

- Optimization of the biodiesel production process by introducing less energy-intensive technologies.

- Application of post-harvest water recycling.

- Application of $\mathrm{CO}_{2}$ from flue gases for algae cultivation.

- $\quad$ Linking algae cultivation and wastewater treatment and biogas production from algal biomass residues.

- Increasing local employability.

4. Essential threats are as follows:

- $\quad$ Promotion of the use of other renewable energy sources in transport such as hydrogen.

- Encouraging the use of battery-electric cars.

- The production of biogas from algae is economically more profitable than the production of biodiesel.

- $\quad$ Production of biodiesel from lignocellulose raw materials has ecological advantages over production from algae.

- $\quad$ The policies of many countries are to reduce the production and sales of diesel cars.

Based on these strengths, opportunities, weaknesses, and threats, stakeholders and policymakers can better understand the issue of biodiesel production from algae and thus make better decisions about investing/not investing in specific research related to improvements in biodiesel production technology and microalgae cultivation.

The key challenges in mass production of biodiesel from algae appear to be high infrastructure, operational, and maintenance costs, along with serious competition from the use of electric cars.

Progress in minimizing/reducing the energy, water, and land-use footprints needs to be a primary objective of enhancing larger-scale algal biodiesel production.

Considering the seriousness of the listed threats, and progress made in the last decade, the author's opinion is that it is not to be expected that large quantities of algae biodiesel will be used in transport soon.

However, possible perspectives in the production of biodiesel from algae can be found in the following:

- $\quad$ Linking biodiesel production and wastewater treatment,

- Algal biomass-based co-products can provide the necessary revenue to reduce the net cost of biodiesel production,

- Developing and applying less energy-intensive technologies for the biodiesel production process,

- Application of algal biodiesel for blending aviation fuel which would lead to a reduction of $\mathrm{CO}_{2}$ emissions from air transport.

Author Contributions: Conceptualization, investigation, methodology, data curation, writing-original draft preparation, visualization, and writing-reviewing and editing, M.B.; writing-reviewing and editing, and data curation, N.S. All authors have read and agreed to the published version of the manuscript.

Funding: This research received no external funding.

Conflicts of Interest: The authors declare no conflict of interest.

\section{References}

1. EUROSTAT. Statistics Explained: Energy Statistics-An Overview. 2020. Available online: https://ec.europa. eu/eurostat/statistics-explained/pdfscache/29046.pdf (accessed on 13 November 2020).

2. EUROSTAT. Statistics Explained: Greenhouse Gas Emission Statistics-Emission Inventories. 2020. Available online: https://ec.europa.eu/eurostat/statistics-explained/pdfscache/30599.pdf (accessed on 13 November 2020). 
3. European Environment Agency (EEA). Emissions of the Main Air Pollutants in Europe; EEA: Copenhagen, Denmark, 2019.

4. UFOP Report on Global Market Supply 2018/2019, Union zur Förderung von Oel- und Proteinpflanzen. Available online: https:/www.ufop.de/files/4815/4695/8891/WEB_UFOP_Report_on_Global_Market_Supply_ 18-19.pdf (accessed on 13 November 2020).

5. Adeniyi, O.M.; Azimov, U.; Burluka, A. Algae biofuel: Current status and future applications. Renew. Sustain. Energy Rev. 2018, 90, 316-335. [CrossRef]

6. Alaswad, A.; Dassisti, M.; Prescott, T.; Olabi, A. Technologies and developments of third generation biofuel production. Renew. Sustain. Energy Rev. 2015, 51, 1446-1460. [CrossRef]

7. Luangpipat, T.; Chisti, Y. Biomass and oil production by Chlorella vulgaris and four other microalgae-Effects of salinity and other factors. J. Biotechnol. 2017, 257, 47-57. [CrossRef] [PubMed]

8. Khan, M.I.; Shin, J.H.; Kim, J.D. The promising future of microalgae: Current status, challenges, and optimization of a sustainable and renewable industry for biofuels, feed, and other products. Microb. Cell Factories 2018, 17, 1-21. [CrossRef]

9. Saad, M.G.; Dosoky, N.S.; Zoromba, M.S.; Shafik, H.M. Algal Biofuels: Current Status and Key Challenges. Energies 2019, 12, 1920. [CrossRef]

10. Kirrolia, A.; Bishnoi, N.R.; Singh, R. Microalgae as a boon for sustainable energy production and its future research \& development aspects. Renew. Sustain. Energy Rev. 2013, 20, 642-656. [CrossRef]

11. Faried, M.; Samer, M.; Abdelsalam, E.; Yousef, R.; Attia, Y.; Ali, A. Biodiesel production from microalgae: Processes, technologies and recent advancements. Renew. Sustain. Energy Rev. 2017, 79, 893-913. [CrossRef]

12. Musa, M.; Ayoko, G.A.; Ward, A.; Rösch, C.; Brown, R.J.; Rainey, T.J. Factors Afecting Microalgae Production for Biofuels and the Potentials of Chemometric Methods in Assessing and Optimizing Productivity. Cells 2019, 8, 851. [CrossRef]

13. Remmers, I.M.; Wijffels, R.H.; Barbosa, M.J.; Lamers, P.P. Can We Approach Theoretical Lipid Yields in Microalgae? Trends Biotechnol. 2018, 36, 265-276. [CrossRef]

14. Naeini, M.A.; Zandieh, M.; Najafi, S.E.; Sajadi, S.M. Analyzing the development of the third-generation biodiesel production from microalgae by a novel hybrid decision-making method: The case of Iran. Energy 2020, 195, 116895. [CrossRef]

15. Weihrich, H. The TOWS matrix-A tool for situational analysis. Long Range Plan. 1982, 15, 54-66. [CrossRef]

16. IRENA. Innovation Outlook: Advanced liquid Biofuels; International Renewable Energy Agency: Abu Dhabi, UAE, 2016.

17. IRENA. Innovation Technology Outlook for Advanced Liquid Biofuels; International Renewable Energy Agency: Abu Dhabi, UAE, 2016.

18. Gielen, D.; Boshell, F.; Saygin, D.; Bazilian, M.D.; Wagner, N.; Gorini, R. The role of renewable energy in the global energy transformation. Energy Strat. Rev. 2019, 24, 38-50. [CrossRef]

19. Namugenyi, C.; Nimmagadda, S.L.; Reiners, T. Design of a SWOT Analysis Model and its Evaluation in Diverse Digital Business Ecosystem Contexts. Procedia Comput. Sci. 2019, 159, 1145-1154. [CrossRef]

20. Iasimone, F.; Panico, A.; De Felice, V.; Fantasma, F.; Iorizzi, M.; Pirozzi, F. Effect of light intensity and nutrients supply on microalgae cultivated in urban wastewater: Biomass production, lipids accumulation and settleability characteristics. J. Environ. Manag. 2018, 223, 1078-1085. [CrossRef]

21. Nzayisenga, J.C.; Farge, X.; Groll, S.L.; Sellstedt, A. Effects of light intensity on growth and lipid production in microalgae grown in wastewater. Biotechnol. Biofuels 2020, 13, 1-8. [CrossRef]

22. Darvehei, P.; Bahri, P.A.; Moheimani, N.R. Modeling the Effect of Temperature on Microalgal Growth under Outdoor Conditions. Comput. Aided Chem. Eng. 2018, 43, 55-60. [CrossRef]

23. Qiu, R.; Gao, S.; Lopez, P.A.; Ogden, K.L. Effects of $\mathrm{pH}$ on cell growth, lipid production and $\mathrm{CO}_{2}$ addition of microalgae Chlorella sorokiniana. Algal Res. 2017, 28, 192-199. [CrossRef]

24. Weyer, K.M.; Bush, D.R.; Darzins, A.; Willson, B.D. Theoretical Maximum Algal Oil Production. BioEnergy Res. 2009, 3, 204-213. [CrossRef]

25. Formighieri, C.; Franck, F.; Bassi, R. Regulation of the pigment optical density of an algal cell: Filling the gap between photosynthetic productivity in the laboratory and in mass culture. J. Biotechnol. 2012, 162, 115-123. [CrossRef]

26. Singh, S.P.; Singh, P. Effect of temperature and light on the growth of algae species: A review. Renew. Sustain. Energy Rev. 2015, 50, 431-444. [CrossRef] 
27. Mata, T.M.; Martins, A.A.; Caetano, N.S. Microalgae for biodiesel production and other applications: A review. Renew. Sustain. Energy Rev. 2010, 14, 217-232. [CrossRef]

28. Shen, Y.; Yuan, W.; Pei, Z.J.; Wu, Q.; Mao, E. Microalgae Mass Production Methods. Trans. ASABE 2009, 52, 1275-1287. [CrossRef]

29. Lee, J.-Y.; Yoo, C.; Jun, S.-Y.; Ahn, C.-Y.; Oh, H.-M. Comparison of several methods for effective lipid extraction from microalgae. Bioresour. Technol. 2010, 101, S75-S77. [CrossRef] [PubMed]

30. Halim, R.; Danquah, M.K.; Webley, P.A. Extraction of oil from microalgae for biodiesel production: A review. Biotechnol. Adv. 2012, 30, 709-732. [CrossRef] [PubMed]

31. Talent, M.; Burgess, G.; Fernández-Velasco, J.G. Protocol to compensate net evaporation and net precipitation in open-pond microalgal massive cultures and permit maximal steady-state productivities. Biomass Bioenergy 2014, 64, 81-90. [CrossRef]

32. Tang, S.; Qin, C.; Wang, H.; Li, S.; Tian, S. Study on supercritical extraction of lipids and enrichment of DHA from oil-rich microalgae. J. Supercrit. Fluids 2011, 57, 44-49. [CrossRef]

33. Chia, S.R.; Show, P.L.; Chew, K.W.; Chen, W.-H.; Phang, S.-M.; Ling, T.C.; Nagarajan, D.; Lee, D.; Chang, J.-S. Sustainable approaches for algae utilisation in bioenergy production. Renew. Energy 2018, 129, 838-852. [CrossRef]

34. Adam, F.; Abert-Vian, M.; Peltier, G.; Chemat, F. "Solvent-free" ultrasound-assisted extraction of lipids from fresh microalgae cells: A green, clean and scalable process. Bioresour. Technol. 2012, 114, 457-465. [CrossRef]

35. Zhu, Y.; Jones, S.B.; Anderson, D.B. Algae Farm Cost Model: Considerations for Photobioreactors. In Algae Farm Cost Model: Considerations for Photobioreactors; Pacific Northwest National Lab.: Richland, WA, USA, 2018.

36. Pankratz, S.; Oyedun, A.O.; Kumar, A. Development of cost models of algae production in a cold climate using different production systems. Biofuels Bioprod. Biorefining 2019, 13, 1246-1260. [CrossRef]

37. Deng, X.-Y.; Gao, K.; Addy, M.; Li, D.; Zhang, R.-C.; Lu, Q.; Ma, Y.-W.; Cheng, Y.-L.; Chen, P.; Liu, Y.-H.; et al. Cultivation of Chlorella vulgaris on anaerobically digested swine manure with daily recycling of the post-harvest culture broth. Bioresour. Technol. 2018, 247, 716-723. [CrossRef]

38. Ye, Y.; Huang, Y.; Xia, A.; Fu, Q.; Liao, Q.; Zeng, W.; Zheng, Y.; Zhu, X. Optimizing culture conditions for heterotrophic-assisted photoautotrophic biofilm growth of Chlorella vulgaris to simultaneously improve microalgae biomass and lipid productivity. Bioresour. Technol. 2018, 270, 80-87. [CrossRef] [PubMed]

39. Přibyl, P.; Cepák, V.; Zachleder, V. Production of lipids in 10 strains of Chlorella and Parachlorella, and enhanced lipid productivity in Chlorella vulgaris. Appl. Microbiol. Biotechnol. 2012, 94, 549-561. [CrossRef] [PubMed]

40. Zhang, Q.; Li, X.; Guo, D.; Ye, T.; Xiong, M.; Zhu, L.; Liu, C.; Jin, S.; Hu, Z. Operation of a vertical algal biofilm enhanced raceway pond for nutrient removal and microalgae-based byproducts production under different wastewater loadings. Bioresour. Technol. 2018, 253, 323-332. [CrossRef]

41. Meng, Y.; Jiang, J.; Wang, H.; Cao, X.; Xue, S.; Yang, Q.; Wang, W. The characteristics of TAG and EPA accumulation in Nannochloropsis oceanica IMET1 under different nitrogen supply regimes. Bioresour. Technol. 2015, 179, 483-489. [CrossRef] [PubMed]

42. Takeshita, T.; Ivanov, I.N.; Oshima, K.; Ishii, K.; Kawamoto, H.; Ota, S.; Yamazaki, T.; Hirata, A.; Kazama, Y.; Abe, T.; et al. Comparison of lipid productivity of Parachlorella kessleri heavy-ion beam irradiation mutant PK4 in laboratory and 150-L mass bioreactor, identification and characterization of its genetic variation. Algal Res. 2018, 35, 416-426. [CrossRef]

43. Li, X.; Přibyl, P.; Bišová, K.; Kawano, S.; Cepák, V.; Zachleder, V.; Č́ižková, M.; Brányiková, I.; Vítová, M. The microalgaParachlorella kessleri-A novel highly efficient lipid producer. Biotechnol. Bioeng. 2012, 110, 97-107. [CrossRef]

44. Shin, Y.S.; Jeong, J.; Nguyen, T.H.T.; Kim, J.Y.H.; Jin, E.; Sim, S.J. Targeted knockout of phospholipase A2 to increase lipid productivity in Chlamydomonas reinhardtii for biodiesel production. Bioresour. Technol. 2019, 271, 368-374. [CrossRef] [PubMed]

45. Song, M.; Pei, H. The growth and lipid accumulation of Scenedesmus quadricauda during batch mixotrophic/heterotrophic cultivation using xylose as a carbon source. Bioresour. Technol. 2018, 263, 525-531. [CrossRef]

46. Rahman, D.Y.; Rachmayati, R.; Widyaningrum, D.N.; Susilaningsih, D. Enhancement of lipid production of Chlorella sp. 042 by mutagenesis. IOP Conf. Ser. Earth Environ. Sci. 2020, 439, 012021. [CrossRef] 
47. Du, Z.-Y.; Alvaro, J.; Hyden, B.; Zienkiewicz, K.; Benning, N.; Zienkiewicz, A.; Bonito, G.; Benning, C. Enhancing oil production and harvest by combining the marine alga Nannochloropsis oceanica and the oleaginous fungus Mortierella elongata. Biotechnol. Biofuels 2018, 11, 174. [CrossRef]

48. Ma, Y.; Wang, Z.; Zhu, M.; Yu, C.; Cao, Y.; Zhang, D.; Zhou, G. Increased lipid productivity and TAG content in Nannochloropsis by heavy-ion irradiation mutagenesis. Bioresour. Technol. 2013, 136, 360-367. [CrossRef] [PubMed]

49. Wei, Z.; Wang, H.; Li, X.; Zhao, Q.; Yin, Y.; Xi, L.; Ge, B.; Qin, S. Enhanced biomass and lipid production by co-cultivation of Chlorella vulgaris with Mesorhizobium sangaii under nitrogen limitation. Environ. Boil. Fishes 2020, 32, 233-242. [CrossRef]

50. Prabakaran, P.; Ravindran, A. A comparative study on effective cell disruption methods for lipid extraction from microalgae. Lett. Appl. Microbiol. 2011, 53, 150-154. [CrossRef] [PubMed]

51. Show, K.-Y.; Lee, D.; Mujumdar, A.S. Advances and Challenges on Algae Harvesting and Drying. Dry. Technol. 2015, 33, 386-394. [CrossRef]

52. Kotasthane, T. Potential of Microalgae for Sustainable Biofuel Production. J. Mar. Sci. Res. Dev. 2017, 7, 223. [CrossRef]

53. Yin, Z.; Zhu, L.; Li, S.; Hu, T.; Chu, R.; Mo, F.; Hu, D.; Liu, C.; Li, B. A comprehensive review on cultivation and harvesting of microalgae for biodiesel production: Environmental pollution control and future directions. Bioresour. Technol. 2020, 301, 122804. [CrossRef]

54. Pan, J.; Muppaneni, T.; Sun, Y.; Reddy, H.K.; Fu, J.; Lu, X.; Deng, S. Microwave-assisted extraction of lipids from microalgae using an ionic liquid solvent [BMIM][HSO 4 ]. Fuel 2016, 178, 49-55. [CrossRef]

55. Porphy, S.J.; Farid, M.M. Feasibility study for production of biofuel and chemicals from marine microalgae Nannochloropsis sp. based on basic mass and energy analysis. ISRN Renew. Energy 2012, 2012, 156824.

56. Al-Ameri, M.; Al-Zuhair, S. Using switchable solvents for enhanced, simultaneous microalgae oil extraction-reaction for biodiesel production. Biochem. Eng. J. 2019, 141, 217-224. [CrossRef]

57. Larrosa, A.; Comitre, A.; Vaz, L.; Pinto, L.A. Influence of Air Temperature on Physical Characteristics and Bioactive Compounds in Vacuum Drying of Arthrospira spirulina. J. Food Process. Eng. 2016, 40, e12359. [CrossRef]

58. Enamala, M.K.; Enamala, S.; Chavali, M.; Donepudi, J.; Yadavalli, R.; Kolapalli, B.; Aradhyula, T.V.; Velpuri, J.; Kuppam, C. Production of biofuels from microalgae-A review on cultivation, harvesting, lipid extraction, and numerous applications of microalgae. Renew. Sustain. Energy Rev. 2018, 94, 49-68. [CrossRef]

59. Samorì, C.; Barreiro, D.L.; Vet, R.; Pezzolesi, L.; Brilman, D.W.F.; Galletti, P.; Tagliavini, E. Effective lipid extraction from algae cultures using switchable solvents. Green Chem. 2013, 15, 353-356. [CrossRef]

60. Karmakar, B.; Halder, G. Progress and future of biodiesel synthesis: Advancements in oil extraction and conversion technologies. Energy Convers. Manag. 2019, 182, 307-339. [CrossRef]

61. Couto, R.M.; Simões, P.; Reis, A.; Da Silva, M.T.L.; Martins, V.H.; Sánchez-Vicente, Y. Supercritical fluid extraction of lipids from the heterotrophic microalga Crypthecodinium cohnii. Eng. Life Sci. 2010, 10, 158-164. [CrossRef]

62. Clarens, A.F.; Nassau, H.; Resurreccion, E.P.; White, M.A.; Colosi, L.M. Environmental Impacts of Algae-Derived Biodiesel and Bioelectricity for Transportation. Environ. Sci. Technol. 2011, 45, 7554-7560. [CrossRef]

63. Davis, R.; Aden, A.; Pienkos, P.T. Techno-economic analysis of autotrophic microalgae for fuel production. Appl. Energy 2011, 88, 3524-3531. [CrossRef]

64. Barros, A.I.; Gonçalves, A.L.; Simões, M.; Pires, J.C. Harvesting techniques applied to microalgae: A review. Renew. Sustain. Energy Rev. 2015, 41, 1489-1500. [CrossRef]

65. Grima, E.M.; Belarbi, E.-H.; Fernández, F.A.; Medina, A.R.; Chisti, Y. Recovery of microalgal biomass and metabolites: Process options and economics. Biotechnol. Adv. 2003, 20, 491-515. [CrossRef]

66. Chen, C.-Y.; Yeh, K.-L.; Aisyah, R.; Lee, D.-J.; Chang, J.-S. Cultivation, photobioreactor design and harvesting of microalgae for biodiesel production: A critical review. Bioresour. Technol. 2011, 102, 71-81. [CrossRef]

67. Delrue, F.; Setier, P.-A.; Sahut, C.; Cournac, L.; Roubaud, A.; Peltier, G.; Froment, A.-K. An economic, sustainability, and energetic model of biodiesel production from microalgae. Bioresour. Technol. 2012, 111, 191-200. [CrossRef]

68. Araujo, V.K.W.S.; Hamacher, S.; Scavarda, L.F. Economic assessment of biodiesel production from waste frying oils. Bioresour. Technol. 2010, 101, 4415-4422. [CrossRef] [PubMed]

69. Molazadeh, M.; Ahmadzadeh, H.; Pourianfar, H.R.; Lyon, S.; Rampelotto, P.H. The Use of Microalgae for Coupling Wastewater Treatment with $\mathrm{CO}_{2}$ biofixation. Front. Bioeng. Biotechnol. 2019, 7, 42. [CrossRef] [PubMed] 
70. Dasan, Y.K.; Lam, M.K.; Yusup, S.; Lim, J.W.; Lee, K.T. Life cycle evaluation of microalgae biofuels production: Effect of cultivation system on energy, carbon emission and cost balance analysis. Sci. Total Environ. 2019, 688, 112-128. [CrossRef] [PubMed]

71. Jegathese, S.J.P.; Farid, M. Microalgae as a Renewable Source of Energy: A Niche Opportunity. J. Renew. Energy 2014, 2014, 430203. [CrossRef]

72. Nhat, P.V.H.; Ngo, H.H.; Guo, W.; Chang, S.; Nguyen, D.; Bui, X.; Zhang, X.; Guo, J. Can algae-based technologies be an affordable green process for biofuel production and wastewater remediation? Bioresour. Technol. 2018, 256, 491-501. [CrossRef] [PubMed]

73. Gendy, T.S.; El-Temtamy, S.A. Commercialization potential aspects of microalgae for biofuel production: An overview. Egypt. J. Pet. 2013, 22, 43-51. [CrossRef]

74. Chen, J.; Li, Q.; Chang, C.; Bai, J.; Liu, L.; Fang, S. Techno-Economic Analysis of Biodiesel Production from Microalgae: A Review. Trends Renew. Energy 2017, 3, 141-152. [CrossRef]

75. Singh, J.; Gu, S. Commercialization potential of microalgae for biofuels production. Renew. Sustain. Energy Rev. 2010, 14, 2596-2610. [CrossRef]

76. Chen, J.; Li, J.; Dong, W.; Zhang, X.; Tyagi, R.D.; Drogui, P.; Surampalli, R.Y. The potential of microalgae in biodiesel production. Renew. Sustain. Energy Rev. 2018, 90, 336-346. [CrossRef]

77. Tredici, M.R.; Rodolfi, L.; Biondi, N.; Bassi, N.; Sampietro, G. Techno-economic analysis of microalgal biomass production in a 1-ha Green Wall Panel $\left(\mathrm{GWP}^{\circledR}\right)$ plant. Algal Res. 2016, 19, 253-263. [CrossRef]

78. Amer, L.D.; Adhikari, B.; Pellegrino, J. Technoeconomic analysis of five microalgae-to-biofuels processes of varying complexity. Bioresour. Technol. 2011, 102, 9350-9359. [CrossRef] [PubMed]

79. Richardson, J.W.; Outlaw, J.L.; Allison, M. The Economics of Microalgae Oil. AgBioForum. 2010, 13, 119-130.

80. Bošnjaković, M. Biodiesel from Algae. J. Mech. Eng. Autom. 2013, 3, 179-188. [CrossRef]

81. Wang, Z.; Calderon, M.M.; Lu, Y. Lifecycle assessment of the economic, environmental and energy performance of Jatropha curcas L. biodiesel in China. Biomass Bioenergy 2011, 35, 2893-2902. [CrossRef]

82. Liu, Z.; Qiu, T.; Chen, B. A LCA Based Biofuel Supply Chain Analysis Framework. Chin. J. Chem. Eng. 2014, 22, 669-681. [CrossRef]

83. Azari, A.; Noorpoor, A.; Bozorg-Haddad, O. Carbon footprint analyses of microalgae cultivation systems under autotrophic and heterotrophic conditions. Int. J. Environ. Sci. Technol. 2018, 16, 6671-6684. [CrossRef]

84. Science Advisory Council EA. GHG Footprints of Different Oil Feedstocks; Science Advisory Council EA: Brussels, Belgium, 2016; pp. 1-12.

85. Slade, R.; Bauen, A. Micro-algae cultivation for biofuels: Cost, energy balance, environmental impacts and future prospects. Biomass Bioenergy 2013, 53, 29-38. [CrossRef]

86. Jacob, A.; Xia, A.; Murphy, J.D. A perspective on gaseous biofuel production from micro-algae generated from CO2 from a coal-fired power plant. Applied Energy 2015, 148, 396-402. [CrossRef]

87. Zhu, L.; Ketola, T. Microalgae production as a biofuel feedstock: Risks and challenges. Int. J. Sustain. Dev. World Ecol. 2011, 19, 268-274. [CrossRef]

88. Baldev, E.; MubarakAli, D.; Saravanakumar, K.; Arutselvan, C.; Alharbi, N.S.; Alharbi, S.A.; Sivasubramanian, V.; Thajuddin, N. Unveiling algal cultivation using raceway ponds for biodiesel production and its quality assessment. Renew. Energy 2018, 123, 486-498. [CrossRef]

89. Rafiqul, I.; Weber, C.; Lehmann, B.; Voss, A. Energy efficiency improvements in ammonia productionperspectives and uncertainties. Energy 2005, 30, 2487-2504. [CrossRef]

90. Demirbas, A. Use of algae as biofuel sources. Energy Convers. Manag. 2010, 51, 2738-2749. [CrossRef]

91. Dai, R.; Wang, P.; Jia, P.; Zhang, Y.; Chu, X.; Wang, Y. A review on factors affecting microcystins production by algae in aquatic environments. World J. Microbiol. Biotechnol. 2016, 32, 1-7. [CrossRef] [PubMed]

92. Lavrinovičs, A.; Juhna, T. Review on Challenges and Limitations for Algae-Based Wastewater Treatment. Constr. Sci. 2017, 20, 17-25. [CrossRef]

93. Moejes, F.W.; Moejes, K.B. Algae for Africa: Microalgae as a source of food, feed and fuel in Kenya. Afr. J. Biotechnol. 2017, 16, 288-301. [CrossRef]

94. Grubišić, M.; Šantek, M.I.; Šantek, B. Potential of Microalgae for the Production of Different Biotechnological Products. Chem. Biochem. Eng. Q. 2019, 33, 161-181. [CrossRef]

95. Clarens, A.F.; Resurreccion, E.P.; White, M.A.; Colosi, L.M. Environmental Life Cycle Comparison of Algae to Other Bioenergy Feedstocks. Environ. Sci. Technol. 2010, 44, 1813-1819. [CrossRef] 
96. Yang, J.; Xu, M.; Zhang, X.; Hu, Q.; Sommerfeld, M.; Chen, Y. Life-cycle analysis on biodiesel production from microalgae: Water footprint and nutrients balance. Bioresour. Technol. 2011, 102, 159-165. [CrossRef]

97. Trivedi, J.; Aila, M.; Bangwal, D.; Kaul, S.; Garg, M. Algae based biorefinery-How to make sense? Renew. Sustain. Energy Rev. 2015, 47, 295-307. [CrossRef]

98. Ge, F.; Xiao, Y.; Yang, Y.; Wang, W.; Moe, B.; Li, X.-F. Formation of water disinfection byproduct 2,6-dichloro-1,4-benzoquinone from chlorination of green algae. J. Environ. Sci. 2018, 63, 1-8. [CrossRef]

99. Rezania, S.; Oryani, B.; Park, J.; Hashemi, B.; Yadav, K.K.; Kwon, E.E.; Hur, J.; Cho, J. Review on transesterification of non-edible sources for biodiesel production with a focus on economic aspects, fuel properties and by-product applications. Energy Convers. Manag. 2019, 201, 112155. [CrossRef]

100. Chew, K.W.; Yap, J.Y.; Show, P.L.; Suan, N.H.; Juan, J.C.; Ling, T.C.; Lee, D.-J.; Chang, J.-S. Microalgae biorefinery: High value products perspectives. Bioresour. Technol. 2017, 229, 53-62. [CrossRef] [PubMed]

101. Suparmaniam, U.; Lam, M.K.; Uemura, Y.; Lim, J.W.; Lee, K.T.; Shuit, S.H. Insights into the microalgae cultivation technology and harvesting process for biofuel production: A review. Renew. Sustain. Energy Rev. 2019, 115. [CrossRef]

102. Dale, B.E.; Anderson, J.E.; Brown, R.C.; Csonka, S.; Dale, V.H.; Herwick, G.; Jackson, R.D.; Jordan, N.; Kaffka, S.; Kline, K.L.; et al. Take a Closer Look: Biofuels Can Support Environmental, Economic and Social Goals. Environ. Sci. Technol. 2014, 48, 7200-7203. [CrossRef] [PubMed]

103. Zhu, L.; Huo, S.; Qin, L. A Microalgae-Based Biodiesel Refinery: Sustainability Concerns and Challenges. Int. J. Green Energy 2015, 12, 595-602. [CrossRef]

104. European Environment Agency. Transport: Increasing Oil Consumption and Greenhouse Gas Emissions Hamper EU Progress towards Environment and Climate Objectives; EEA: Copenhagen, Denmark, 2020.

105. Jard, G.; Marfaing, H.; Carrère, H.; Delgenes, J.; Steyer, J.; Dumas, C. French Brittany macroalgae screening: Composition and methane potential for potential alternative sources of energy and products. Bioresour. Technol. 2013, 144, 492-498. [CrossRef]

106. Campbell, J.E.; Lobell, D.B.; Field, C.B. Greater Transportation Energy and GHG Offsets from Bioelectricity Than Ethanol. Science 2009, 324, 1055-1057. [CrossRef]

107. Nijs, S.D. Reducing the Emissions of GHGes from Ships by Using Biofuel Made from Microalgae. Master's Thesis, Ghent University, Ghent, Belgium, 2018.

108. Jacquin, A.-G.; Brulé-Josso, S.; Cornish, M.L.; Critchley, A.T.; Gardet, P. Selected Comments on the Role of Algae in Sustainability. In Advances in Botanical Research; Elsevier BV: Amsterdam, The Netherlands, 2014; pp. 1-30.

Publisher's Note: MDPI stays neutral with regard to jurisdictional claims in published maps and institutional affiliations.

(C) 2020 by the authors. Licensee MDPI, Basel, Switzerland. This article is an open access article distributed under the terms and conditions of the Creative Commons Attribution (CC BY) license (http://creativecommons.org/licenses/by/4.0/). 